\title{
SECURING HUMAN RIGHTS IN THE FACE OF INTERNATIONAL INTEGRATION
}

\author{
ISRAEl DE Jesús ButLeR*
}

\begin{abstract}
The continuous transfer of authority from the national sphere to inter-governmental organizations gives rise to an increasing risk that States may be mandated by their obligations under these organizations to take measures that are inconsistent with their obligations under International Human Rights Law. Drawing on the approaches of various international, regional and national jurisdictions, this article explores two possible models for restructuring International Law that could ensure that human rights obligations remain effective. The 'international constitutional' approach would ensure that human rights are enshrined within the 'constitutional' instruments of IGOs, preventing incompatible rules from emerging. The 'parochial' approach would ensure that human rights as protected at the national or regional level would take precedence over conflicting international obligations.
\end{abstract}

Traditionally, the potential abuse of State authority has represented the largest threat to individuals. While this danger remains real, steps have been taken to curb State excesses through the creation of international human rights instruments. The UN Charter itself (particularly through subsequent interpretation of its provisions by UN organs) imposes obligations in the field of human rights on all its members, ${ }^{1}$ and every State is party to at least one other treaty that sets out human rights guarantees. ${ }^{2}$

At the same time, the structure of international society is changing. The State is no longer the exclusive decision-maker and administrator over its territory because, to varying degrees, it has come to share these roles with

* Israel de Jesús Butler BA (Cantab), LLM (Nottingham), PhD (Nottingham), Seconded National Expert and researcher at the European Union Agency for Fundamental Rights; Lecturer in Law, Law School, Lancaster University. All views and opinions expressed in this article remain those of the author and do not purport to reflect the views or policy of the Fundamental Rights Agency. The author would like to thank Robert McCorquodale, Steven Wheatley and Nigel White, Sigrun Skogly and the anonymous reviewer for their extremely helpful comments. All mistakes, of course, remain my own. Email: i.butler@lancaster. ac.uk; Israel.butler@fra.europa.eu.

${ }^{1}$ See I Butler, 'Unravelling Sovereignty: Human Rights Actors and the Structure of International Law' (Intersentia, 2007) ch 3.

${ }^{2}$ For status of ratifications and accessions see: http://treaties.un.org/Pages/Treaties. aspx?id=4\&subid=A\&lang=en, visited 16 December 2010 . 
other entities, particularly inter-governmental organizations (IGOs). ${ }^{3}$ IGOs have varying degrees of autonomy from their Member States, and often have a distinct legal personality. Few constituent treaties of IGOs contain any provisions regarding human rights protection, unless they are created with that specific aspect in mind. Therefore, there is a risk that the more States cooperate through IGOs, the greater the likelihood that these may authorize or oblige their members to act in such a way that conflicts with the human rights guarantees they hold individually. These conflicts could be resolved through application of the rules of hierarchy in international law (discussed below), which address questions of priority between competing obligations among States. Current rules relating to hierarchy in international law prove inadequate for the protection of human rights because, generally speaking, they are based around the procedural issue of chronology, rather than the substantive issue of compatibility with human rights. Furthermore, human rights obligations, unlike most rules of international law, apply not only between States but also between States and individuals. The UN's Human Rights Committee has gone so far as to state that once undertaken by a State, human rights guarantees devolve to the population and cannot be revoked. ${ }^{4}$ Arguably, human rights have become a permanent feature of the international legal landscape and perhaps even part of the legal heritage of humankind.

In light of the above, this article explores how international law could be remodelled to ensure that human rights guarantees continue to be observed even as States continue towards integration through IGOs. It will focus in particular on the UN, given its capacity and practice of issuing binding decisions upon its members through Security Council (SC) Resolutions. It does not intend to theorize how human rights law could be applied to IGOs, or whether current legal doctrine subjects IGOs to human rights obligations. That is, the focus of the argument is not that IGOs are bound by human rights standards. Rather, the challenge is to explore two different models of international law capable of ensuring the preservation of human rights guarantees in the face of international integration by States into IGOs. The first model to

3 P Alston (ed), 'Non-State Actors and Human Rights' (OUP, Oxford, 2005); A Clapham, Human Rights Obligations of Non-State Actors (OUP, Oxford, 2006). Inter-governmental organization is understood to mean an 'inter-state body created by multilateral treaty ... [with] what may be called a constitution ... [and] organs separate from its members'. CF Amerasinghe, 'Principles of Institutional Law of International Organizations' (2nd edn, CUP, Cambridge, 2005) 9-10.

4 See UN Human Rights Committee General Comment 26, 'Continuity of Obligations' (8 December 1997) CCPR/C/21/Rev.1/Add.8/Rev.1. The wording used by the HRC in the General Comment is: 'the rights guaranteed under the Covenant belong to the people living in the territory of a State party, and that once the people are accorded the protection of the rights under the Covenant, such protection devolves with territory and continues to belong to them, notwithstanding changes in the administration of that territory'. 
be explored is termed 'international constitutional', meaning that that human rights are guaranteed at a constitutional level in international law, ensuring that the validity of any rule to emerge from an IGO is subject to its compliance with human rights standards. The second model is termed 'parochial'. This approach would guarantee human rights within a legal system-be it at national or regional level - in such a way that laws emanating from external legal systems would not be given effect where they conflicted with that jurisdiction's human rights standards.

These models are explored with reference to the decisions of different European jurisdictions. As will be discussed below, the UK Supreme Court, European Court of Human Rights, (ECtHR) Court of Justice of the European Union (CJEU) and General Court of the EU (GC) have all accepted the notion of a hierarchy of norms in international law in examining the relative weight of United Nations SC Resolutions vis-à-vis human rights treaties, but not all of them have given effect to this hierarchy. Given the potential breadth of analysis, the piece will focus on obligations stemming from the UN, particularly those originating in SC Resolutions adopted in the context of maintaining international peace and security. It is in this context, generally during the course of its counter-terrorism measures, that the flash-points between human rights obligations and other international obligations have occurred. However this particular context does not diminish the pertinence of the more general application of the observations made for other IGOs with the potential to threaten human rights protection.

\section{CONSTITUTIONALISM AND PAROCHIALISM AND RELATED DEBATES}

\section{A. The 'International Constitutional' and 'Parochial' Approaches}

The 'international constitutional' and 'parochial' models proposed here are human rights- centred models of international law. They each represent an alternative means of ordering the relationship between national and international law, and different obligations within international law itself, in such a way that ensures the human rights guarantees undertaken by States remain effective. If human rights obligations are to be considered permanent in the sense that they are valid for individuals within a State's territory and jurisdiction, and that they cannot be revoked by the State, it is necessary to clarify what shape the international system could or should take to ensure this.

The answer to this depends on how one views the system itself: is it (should it be?) hierarchical, or 'parochial'? As is discussed below, this goes beyond the monist versus dualist debate as well as the question of human rights as a lex specialis. The issue is not merely whether international law should penetrate the domestic sphere automatically, nor whether, in certain circumstances, the rules of human rights law should displace those of general

\section{CAMbridge JOURNALS}


international law (eg relating to the validity of treaty reservations). ${ }^{5}$ Rather, the question is whether obligations of a 'higher' international order should penetrate those of a 'lower' order where they fail to observe human rights guarantees.

According to an 'international constitutional' model, human rights would be guaranteed within international law at a level higher than all other obligations. While some precedent exists in international law for this with the existence of rules of jus cogens, protection of human rights through this means cannot be considered concrete or clear. As is discussed below, the content of jus cogens is too narrow and too uncertain for this purpose. Rather, an 'international constitutional' model would fix human rights within the constitutions of all IGOs to ensure that no rules generated by such organizations, binding on their Member States, could conflict with human rights standards. Such a top-down approach would place human rights guarantees at the top of a pyramid of international obligations, allowing for States to implement their IGO-derived obligations without the danger of abrogating or defaulting on human rights obligations that already exist in international law.

It should be noted that the term 'constitutional' is used here simply to capture the idea of protecting human rights from the top-down via the constitutions or founding treaties of IGOs. It does not imply that any particular IGO should be seen to represent an overarching international constitution, nor that IGOs themselves should be democratized or in any other way 'legitimated' to the people of the world. ${ }^{6}$

A 'parochial' approach would see human rights protected at a lower level. Rather than fixing human rights protection at a higher point in international law, States would filter international obligations at the national or regional level. Wherever international obligations conflict with national or regional human rights rules, any rule of international law would be denied effect within that jurisdiction.

\section{B. Related Debates: Monism vs Dualism and Legal Pluralism}

\section{Monism and Dualism}

It may be asserted that 'constitutionalism' and 'parochialism' merely recast the concepts of 'monism' and 'dualism' that already exist in legal theory.

5 Compare arts 19-23 of the Vienna Convention on the Law of Treaties 1969 (1155 UNTS 331) with UN Human Rights Committee General Comment 24 'On issues relating to reservations made upon ratification or accession to the Covenant or the Optional Protocols thereto, or in relation to declarations under article 41 of the Covenant' (11 November 1994) CCPR/C/21/Rev.1/ Add.6.

${ }^{6}$ See eg E-U Petersmann, 'How to Reform the UN System? Constitutionalism, International Law, and International Organizations' (1997) 10 Leiden Journal of International Law 421; B Fassbender, 'The United Nations Charter as the Constitution of the International Community' (1998) 36 Columbia Journal of Transnational Law 529.

\section{CAMBridge}


According to the monist view, international and domestic law form a single, continuous legal system, where international law should penetrate the domestic sphere automatically and take precedence over conflicting domestic laws. ${ }^{7}$ According to the dualist perspective, international law and domestic law coexist as parallel and distinct legal systems, where international obligations may enter the domestic realm only upon the satisfaction of certain requirements, such as the incorporation of international obligations into national legislation. ${ }^{8}$ However, it is not possible to equate monism with 'constitutionalism' and dualism with 'parochialism'. ${ }^{9}$ The question posed here is how human rights can be guaranteed in a context of multiple webs of international obligations undertaken by States. Conceiving of the relationship between national and international law in monist or dualist terms cannot provide a complete answer, for two reasons.

Firstly, monism and dualism concern the broader structural question of the relationship between national law and international law, and whether there is a continuous legal system. This debate of itself says nothing about the substance of the rules in the national or international legal system. A monist model of international law does not accord priority to laws depending on their substantive content, but according to their origin (as international or national). ${ }^{10}$ Such a view of the legal order does not necessarily ensure the persistence of international human rights obligations at the national level, since these obligations co-exist with other competing international obligations. Thus the substantive rules that penetrate national law depend on a prior decision on which competing international obligations prevail. ${ }^{11} \mathrm{~A}$ dualist model of

7 There is some difference of opinion over whether monism implies that international law automatically enters national law, or whether a prior rule of domestic law is necessary to grant international law this status. See F Morgenstern, 'Judicial Practice and the Supremacy of International Law' (1950) 27 British Yearbook of International Law 42. There is also some difference of opinion over whether monism implies that international law is automatically superior to national law, or whether this should be left to the national judge to decide. See review of literature in RP Schaffer, 'The Inter-Relationship between Public International Law and the law of South Africa: an Overview' (1983) 32 ICLQ 277, 281-282.

${ }^{8}$ For a discussion of the monist and dualist traditions see: G Fitzmaurice, 'The General Principles of International Law Considered from the Standpoint of the Rule of Law' (1957-II) 92 Hague Receuil 1, 70-80; E Margolis, 'Soviet Views on the Relationship between National and International Law' (1955) 4 ICLQ 116; L Preuss, 'The Relation of International Law to Internal Law in the French Constitutional System' (1950) 44 AJIL 641.

9 The nuances and intricacies of the monist-dualist debate are slightly simplified here. It is hoped that the level of detail is sufficient to present the two approaches sufficiently to distinguish them from 'constitutionalism' and 'parochialism'.

${ }^{10}$ For Kelsen, national law derives its validity from international law, because international law establishes the scope of application of national law. The only reason that the law of a particular State applies within that State's jurisdiction to the exclusion of the laws of other States is because international law regulates the territorial scope of each States' laws. It would follow that international law is therefore superior to and take precedence over national law. Accordingly, international law and national law form part of a single legal system. See H Kelsen, 'The Pure Theory of Law and Analytical Jurisprudence' (1941) 55 Harvard Law Review 44, 66-70.

11 This issue of hierarchy is addressed below. 
international law merely maintains that national and international law coexist as separate regimes, and that international law must be admitted into national law by a positive act of the State, such as the incorporation of international obligations into national legislation. ${ }^{12}$ Again, the substance of the national and international obligations is irrelevant to the issue of which takes priority at the national level. That is determined simply according to whether the obligation was created at the national or at the international level.

Secondly, the discussion here goes beyond the monism/dualism debate because the latter says nothing about priority between obligations within international law itself (as opposed to the interface between national and international law). The monist/dualist debate fails to make allowance for the existence of parallel and potentially conflicting obligations at the international level. A monist system could not purport to guarantee human rights obligations in the national sphere unless these obligations happened to be superior to other conflicting rules of international law by the time that they 'arrived at the door' of national law. This question is itself then dependent on the issue of hierarchy or priority of obligations in international law, which is discussed further below. Similarly, a dualist system could not purport to guarantee human rights obligations unless these already happened to be entrenched in national law.

Viewing the international system in monist or dualist terms provides no answer as to which of those rules should take priority over the other. Rather the 'constitutional' and 'parochial' models argue for a substantive human rights 'check', given effect either at the international, regional or national level. Under a 'constitutionalist' approach international law does not necessarily have to penetrate national law automatically. Rather, a 'constitutionalist' approach ensures that human rights are accorded priority among competing international obligations by placing them within the constitutions or founding treaties of IGOs. This then prevents the organization from creating obligations for its Member States that would contradict these. A 'parochial' approach resembles a dualist model of international law in that it does not automatically admit international obligations into national law. The principal difference is that the condition for 'admittance' is not a positive act by the State, but rather the satisfaction of the criteria of being compatible with that State's human rights guarantees that exist in national law.

12 For a discussion of the practice of various States in this regard see JH Jackson, 'Status of Treaties in Domestic Legal Systems: A Policy Analysis' (1992) 86 AJIL 310. Brownlie explains dualism in the following terms: 'International law is a law between sovereign states: municipal law applies within a state and regulates the relations of its citizens with each other and with the executive. On this view neither legal order has the power to create or alter rules of the other. When municipal law provides that international law applies in whole or in part within the jurisdiction, this is merely an exercise of authority of municipal law, an adoption or transformation of the rules of international law. In case of a conflict between international law and municipal law the dualist would assume that a municipal court would apply municipal law.' I Brownlie, 'Principles of Public International Law' (7 ${ }^{\text {th }}$ edn, OUP, Oxford, 2008) 31-32. 


\section{Legal Pluralism}

The term 'legal pluralism' is used to describe (among other things) the phenomenon of various legal regimes competing to apply to or regulate one particular situation. It has been greeted of late with enthusiasm for the potential advantages that diverse parallel legal systems might present, such as alternative solutions to common problems. ${ }^{13}$ However, the author wishes to focus on how, pragmatically speaking, one might better protect human rights. Such an approach does not necessarily advocate pluralism as a model of international law or the relationship between national and international legal systems. The author's arguments are based on the premise that the correct model of international law is that which can guarantee the perpetuation of human rights guarantees. The pluralist debate is of limited relevance here. Neither the international constitutional nor the parochial approaches necessarily advocate diversity among coexisting legal systems. Indeed, they both advocate a significant degree of uniformity, in that both models are geared towards the guarantee of a particular set of rules. 'Plurality' merely describes the current situation of overlapping legal systems. What the author wishes to focus on is how to ensure that within this diversity a particular legal regime (the one implementing human rights) can be prioritized over others.

\section{INADEQUACY OF THE CURRENT HIERARCHY OF NORMS FOR HUMAN RIGHTS PROTECTION}

The following section will explore the current 'system' of hierarchy in international law and its implications for human rights protection. ${ }^{14}$ The relatively basic approach to prioritization between obligations in international law proves inadequate and is even inimical to the protection of human rights. While international law already provides rules for ordering priority between competing obligations this system generally (with the exception of jus cogens rules) places its emphasis on procedural issues (eg priority between rules determined by chronology) rather than questions relating to the substance of the rules themselves. Given the multiplication of global and regional treaties, particularly those establishing IGOs, a system of hierarchy that largely ignores the substance of conflicting rules in order to determine their validity will inevitably undermine the protection of human rights. The inadequacy of

13 The content of this article might serve as an empirical example of pluralism. See, eg F Berman, 'A Pluralist Approach to International Law' (2007) 32 Yale Journal of International Law, 301; BZ Tamanaha, 'Understanding Legal Pluralism Past to Present, Local to Global' St. John's Legal Studies Research Paper Series, Paper No. 07-0080, May 2008 available on: http://ssrn.com/abstract=1010105, accessed 16 December 2010.

${ }_{14}$ Even writers concerned about the legitimacy or desirability of establishing a hierarchy of norms admit that there has emerged at the international level a relativity among the value of different legal obligations with certain norms having different legal value. See P Weil, 'Towards Relative Normativity in International Law?' (1983) 77 AJIL 413.

\section{CAMbridge JOURNALS}


international law to guarantee human rights underlines the need for a new approach to international law in order to ensure their protection.

\section{A. Hierarchy between Rules of International Law}

The idea of hierarchy in international law is not well developed. ${ }^{15}$ The existence of a hierarchy of norms, in the sense that Kelsen described, where each rule derives its validity from a higher rule, exists only in a limited sense. ${ }^{16}$ The concept of jus cogens shows that those rules which have been recognized by the international community as a whole as of fundamental importance will take precedence over others. ${ }^{17}$ According to article 64 of the Vienna Convention on the Law of Treaties (VCLT) - which is reaffirmed by article 26 of the Draft Articles on State Responsibility - treaty-law conflicting with rules that have attained jus cogens status will not be valid. ${ }^{18}$ Thus, there do exist rules of international law that take priority over all others. It might therefore be argued that the protection of human rights through an 'international constitutional' approach to international law already exists through rules of jus cogens. However, it is extremely difficult to rely on rules of jus cogens for the protection of human rights because so few rules have been recognized as having attained this status. While the case-law of the Inter-American Commission of Human Rights has recognized rules of jus cogens quite liberally, most other international judicial bodies (such as the European Court of Human Rights and the International Court of Justice) have been far more cautious in making such pronouncements. ${ }^{19}$

15 It seems to be generally agreed that art 38 of the Statute of the International Court of Justice did not intend to create a hierarchy in its ordering of different sources of law available to the Court. Akehurst's analysis rejects that-apart from rules of jus cogens - there is any inherent hierarchy among the sources of law listed in art 38 of the ICJ Statute: 'treaties are easier to prove than custom and custom is easier to prove than general principles of law; that is one reason why they are likely to be applied in that order, and perhaps why Articles 38 lists them in that order.' See 'The Hierarchy of the Sources of International Law' (1974-75) 47 British Yearbook of International Law 273, 274.

${ }^{16}$ For an exploration of what is actually meant by the idea of a hierarchy of law or norms in international law see: P Weiler and AL Paulus, 'The Structure of Change in International Law or Is there a Hierarchy of Norms in International Law?' (1997) 8 EJIL 545; M Koskenniemi, 'Hierarchy in International Law: A Sketch' (1997) 8 EJIL 566.

17 Vienna Convention of the Law of Treaties (1155 UNTS 331), arts 53 and 64.

18 International Law Commission, 'Articles on Responsibility of States for Internationally Wrongful Acts, with commentaries' Yearbook of the International Law Commission (2001) Vol II, Part Two, 84-85. The case law applying the principle has also extended this to the validity of rules of national law. See cases from the Inter-American system, below (n 19). While the Articles on State Responsibility are not themselves legally binding the commentary supports the view that this is a valid rule of international law.

19 For a discussion of Inter-American case-law see I Butler, 'The US and Brazil before the Inter-American Commission on Human Rights: Recent Cases' (2004) 4 Human Rights Law Review 2 295, 304-308. See eg Roach and Pinkerton v USA IACnHR Case No. 9647, Res. No. 3/ 87 (1987) paras 56, 60; Miguel Dominguez v USA IACnHR Case 12.285, Report No. 62/02 (2002), paras 83-84; 'Gómez-Paquiyauri Brothers'v Peru IACtHR, Series C 110 (2004), para 128; Maritza Urrutia v Guatemala Series C 103 (2003), paras 92, 100-101. Other courts have 
If jus cogens cannot be relied upon to ensure the protection of human rights, what of the range of regional and global human rights treaties? Unfortunately, while a considerable number of human rights instruments exist, there is nothing within them to suggest a superior status over other rules. In the absence of such a provision, the normal rules relating to priority among particular treaties must be applied. Similarly to customary international law, the principle of lex posterior derogat priori is affirmed by the VCLT. ${ }^{20}$

A later agreement on a matter between the same parties will take priority over an earlier agreement. To the extent that the subject matter and identity of the parties is not identical, a State's obligations towards other States will differ accordingly. This general rule does little to set an objective hierarchy, given the web of treaties to which States are party, but does give guidance on how to determine priority between conflicting obligations. ${ }^{21}$ Some treaties, particularly those that establish IGOs, contain specific provisions relating to their status relative to other agreements. These might be termed 'supremacy clauses'. For example, the UN Charter, which will be discussed below, contains article 103, according it priority over any other agreement that States have entered. Other treaties appear more modest. Thus, for instance, the Treaty on the Functioning of the European Union (TFEU) preserves treaty obligations entered into by Member States before joining the EU as towards third States, but takes priority over those obligations as between the Member States. It also requires Member States to eliminate incompatibilities as soon as possible. ${ }^{22}$

been far more cautious in recognizing rules of this nature. The International Court of Justice found that the prohibition on genocide constituted a 'peremptory norm' in the Case Concerning Armed Activities on the Territory of the Congo (New Application: 2002) (Democratic Republic of Congo $v$ Rwanda) [2006] ICJ Rep 6, 27. The European Court of Human Rights found that the prohibition on torture could be seen as a rule of jus cogens: Al-Adsani v UK (2002) 34 EHRR 273, para 61. This was also the opinion of the International Criminal Tribunal for the former Yugoslavia: Prosecutor $v$ Furundzija IT-95-17/I-T, para 144. Recently the General Court of the EU also addressed the concept in two cases: Cases T-315/01 Kadi $v$ Council and Commission (21 September 2005) para 226 and Yusuf and Al Barakaat International Foundation v Council and Commission T-306/01 (21 September 2005) para 277. The principle has been thoroughly explored by A Orakhelashvili 'Peremptory Norms in International Law' (Oxford, OUP, 2006). See also: R Jennings and A Watts (eds), Oppenheim's International Law Volume I Peace, Parts 24 (9th edn, OUP, Oxford, 1992); J Charney, 'Universal International Law' (1997) 87 AJIL, 529; Christenson, 'The World Court and Jus Cogens' (1987) 81 AJIL, 93. D Shelton, 'Hierarchy in International Law' 100 (2006) AJIL, 291.

20 Akehurst (n 15).

21 Orakhelashvili (n 19) 7. Orakhelashvili writes that among treaties 'instances of hierarchy are based on the conception of international law as a consent-based system of norms derived from the will of States. Assumptions that a later norm prevails over an earlier one or that it does not so prevail because the States concerned have so wished, or that a norm applicable between a limited number of States can trump general international law all imply that the will of States determines the priority of norms. This means that there is no categorical hierarchy of international instruments, for no instrument is inherently superior to another. The issues of hierarchy arise only in the specific cases when the clauses of different instruments come into conflict with each other and the rule which prevails does so because this was so wished by the relevant States for this specific case.' art 307 .

Art 351 of the Treaty on the Functioning of the European Union. Formerly, EC Treaty,

\section{CAMBridge JOURNALS}


The North American Free Trade Agreement (NAFTA) reaffirms commitments to all States under the World Trade Organisation, but then provides that the NAFTA Agreement shall prevail over all other agreements. ${ }^{23}$ The Treaty of the Economic Community of West African States (ECOWAS) permits States parties to conclude agreements with third States or organizations insofar as these are compatible with the ECOWAS treaty, and provides that agreements entered into prior to the creation of ECOWAS should be removed if they are incompatible. ${ }^{24}$ Some treaties however, contain little or no guidance on how to resolve a conflict with other agreements. For example, the Agreement Establishing the World Trade Organisation does not seem to contain a provision on priority, ${ }^{25}$ and the Articles of Agreement of the International Monetary Fund provide for negotiation of a mutually acceptable solution between parties where IMF obligations may conflict with obligations contained in a prior agreement, but only in limited circumstances. ${ }^{26}$

International law is not a particularly refined hierarchical system in that treaties, in practice, do not derive their validity from superior rules. Rather, they derive their validity from the procedural circumstance of having been created through State consent and-barring some procedural defect-will remain valid unless they conflict with a rule of jus cogens. ${ }^{27}$ At the same time States may maintain separate sets of conflicting rules with different groups of States quite freely so long as they remain able to perform their respective obligations. If treaties are a source of obligation rather than a source of law it is possible to accept that there exists a plurality of legal regimes on an equal level-a kind of heterarchy. ${ }^{28}$ In this sense the most that international law

${ }^{23}$ NAFTA Agreement, art 103. Consolidated text provided by NAFTA secretariat on http:// www.nafta-sec-alena.org/en/view.aspx?conID=590\&mtpiID=ALL\#103, accessed 16 December 2010.

${ }^{24}$ Art 84. Available on the ECOWAS website: http://www.comm.ecowas.int/sec/index. php?id=treaty\&lang=en, accessed 16 December 2010.

${ }_{25}$ Text available on the WTO website: http://www.wto.org/english/docs_e/legal_e/04-wto. pdf, accessed 16 December 2010.

${ }^{26}$ Art VIII, s 6. Full text available on the IMF website: http://www.imf.org/external/pubs/ft/ aa/index.htm, accessed 16 December 2010.

27 It is not that rules become valid because they derive from a higher body of jus cogensindeed the reverse is true since a rule of jus cogens will only come into being once it has been accepted by the international community as a whole and so will have most probably been a rule of customary international law or treaty law first. Similarly, the limited body of rules of jus cogens quality could not be said to have spawned the breadth of existing international law.

${ }^{28}$ C Salcedo, 'Reflections on the Existence of a Hierarchy of Norms in International Law' (1997) 8 EJIL 583, 584 notes that 'most rules of international law are only authoritative for those subjects that have accepted them. The relativism of international law may thus lead to a clash between the unilateral legal claims of states, as each state is free to assess the scope of the obligations it has assumed and is on an equal footing with every other state as regards the interpretation of its commitments ... international norms are relative because their scope varies according to states' commitments: each state which has actively or passively subjected itself to the effects of those norms, is bound by them to every other state which has done the same. To be sure, the sovereign state must comply with international law, but it is up to each state to assess the requirements of that law in each situation and in each specific case.' (emphasis in original). 
does in practice is to provide a means of assessing priority between conflicting rules, rather than establishing a pre-defined hierarchy.

Thus, successive treaties on the same subject matter between the same parties - subject to express exceptions, such as those given above-will take priority over earlier treaties, as between those parties. It might be objected that this poses no threat to human rights protection. If one treaty only takes priority over another to the extent that the same subject matter is covered, then the only kind of treaty that can take priority over a human rights treaty is another human rights treaty. However, the problem lies in the cross-cutting nature of human rights. A treaty regulating any subject matter can potentially have an impact on human rights guarantees, even if it does not expressly relate to the same issue. This much can be seen from the conflicts between rules relating to free trade and human rights in the context of the (then) European Economic Community. ${ }^{29}$

Apart from the potential confusion that may arise for governments as to the scope and beneficiaries of their obligations a very grave problem exists from the perspective of human rights. ${ }^{30}$ There is a danger when particular treaties provide for priority over other agreements, including human rights treaties, or are silent on the matter but concluded subsequently to human rights treaties. ${ }^{31}$ Here the State may be faced with a conflict between its human rights obligations and other duties towards third States. The situation is more pronounced where the treaty in question has created an IGO, since often (either implicitly or explicitly) the IGO will possess legal personality and a degree of power to act autonomously of its individual State members. It is rare for the constitutive instruments of most IGOs - unless expressly created for that purpose- to contain human rights guarantees, nor are most (if any) IGOs party to human rights instruments, which means that there may well be no internal human rights 'check' to ensure that their decisions do not result in violations. The principal exception to this will be the EU, which intends to accede to the UN Convention on the Rights of Persons with Disabilities and the European Convention on Human Rights. ${ }^{32}$

29 See eg Case 29/69 Stauder v Ulm [1969] ECR 419.

30 Over a decade ago CF Amerasinghe, Principles of Institutional Law of International Organizations (CUP, Cambridge, 2005) 6, estimated the number of IGOs was between 500 and 700 .

31 On the problem of conflicting treaties in the context of the EU Member States vis-à-vis third States see $\mathrm{T}$ Hartley, 'International Law and the Law of the European Union-a Reassessment' (2001) 72 British Yearbook of International Law 1, 22-35.

32 See: Council Decision 2010/48 concerning the conclusion, by the European Community, of the United Nations Convention on the Rights of Persons with Disabilities, OJ L 23, 27.1.2010, p. 35; Article 44 of the Disabilities Convention (UN Doc. A/61/611, 13 December 2006); Protocol 14bis to the European Convention (CETS No.: 204, 27/5/2009) and Article 6(2) of the Treaty on European Union (as amended by the Lisbon Treaty, OJ C 83, 30.3.2010, 13).

\section{CAMBRIDGE}




\section{B. Hierarchy between Rules of International and National Law}

At the interface of international and national law, article 27 of the VCLT (reaffirmed by article 3 of the Draft Articles on State Responsibility) ${ }^{33}$ prohibiting States from using national law as an excuse for failure to execute international obligations, implicitly accepts that while national and international law may co-exist on different planes, international law should take priority between States. ${ }^{34}$ That is not to say that article 27 obliges the State to change its national law (though a pure monist might argue that this is the case), but it does confirm that at the international level it is international law and not national law that takes priority. ${ }^{35}$ The rules of national law, usually as interpreted by the national courts, then determine the extent to which the rule may apply domestically. ${ }^{36} \mathrm{~A}$ tradition conforming to a true 'monist' position will allow international law to penetrate into and take precedence over national law, while a 'dualist' tradition will permit entry of international law into national law only to the extent that it satisfies certain conditions. ${ }^{37}$

Thus under the current model of international law, States may be obliged to prioritize international commitments conflicting with prior human rights commitments. In addition to this they may not use human rights guaranteed at the national level as justification for refusing to implement these obligations. If a State chooses to prioritize national human rights law over international commitments, it will engage its international responsibility with regards to those States to which that obligation is owed.

From the foregoing, the following observations can be made. Firstly, while rules of jus cogens will prevail over conflicting rules, they are an inadequate vehicle for guaranteeing human rights protection, given their potentially vague and sparse content. Secondly, the rules for assessing priority between treaties obliges States to give effect over latterly created obligations, irrespective of their conflict with earlier human rights obligations. Thirdly, States

\footnotetext{
33 See International Law Commission (n 18) 36-38. The commentaries support the view that this rule forms part of customary international law.

34 This expectation that States will adjust their domestic laws to ensure observance of their international obligations is neatly labelled a 'presumption against hypocrisy' by Dyzenhaus. He points to the common law jurisdictions of the UK, New Zealand, Australia and Canada as examples where the domestic courts, while unable to apply treaty-law directly, have ensured that existing national law is interpreted consistently with international obligations. D Dyzenhaus, 'The Rule of (Administrative) Law in International Law' (2005) 68 Law and Contemporary Problems 127, 133-137.

35 Hartley (n 31) 2 notes 'international law and the national (municipal) law of a State are two different legal systems. This follows from the fact (if from no other) that it is possible to have two mutually incompatible rules, one in international law and one in national law, each of which is valid in its own system. Thus a statute passed by a State might be contrary to international law; yet it may nevertheless be valid in its own system. This would not be possible if the two were part of the same legal system.'

${ }^{36}$ For a comparative discussion of the role of national courts in interpreting and giving effect to treaties domestically see C Schreuer, 'The Interpretation of Treaties by Domestic Courts' (1971) 45 British Yearbook of International Law 255.

37 See sources cited above (n 7-12).
} 
are expected to ensure that their national law conforms to their international obligations, insofar as national law is relevant to inter-State relations. Accordingly, the current model of international law, given the context of increasing international integration, is inadequate to ensure that human rights obligations continue to be guaranteed. The article will now discuss the different possibilities for ensuring the continued protection of human rights.

\section{THE 'INTERNATIONAL CONSTITUTIONAL' APPROACH}

This approach to human rights protection would ensure that obligations created in the context of an IGO would themselves have to comply with human rights standards in order to be considered valid. Thus, a human rights 'quality control' would exist at the point of origin, meaning that (in theory) States members executing such obligations at the national level would never face a situation where they were under a duty to commit violations by virtue of their membership of the IGO in question. ${ }^{38}$ Under an 'international constitutional' approach there would exist, ideally, an ex ante human rights impact assessment of proposed treaties and decisions. There should also be envisaged an ex post facto control through judicial review within the IGO through its own judicial organs (if any), where individual victims or interested parties might call for verification of compliance.

\section{A. A Priori Check}

Currently within the UN there exists no routine prior verification that decisions taken by its institutions, or treaties elaborated in the context of the organization, actually comply with States members' human rights obligations. Exceptionally one might note the Security Council's Counter-Terrorism Committee. The CTC, responsible for monitoring and providing assistance to States in building capacity to prevent and combat terrorist activity, is required to seek advice at a general level on human rights from the UN's Office of the High Commissioner for Human Rights, but this does not seem to amount to the vetting or review of its decisions or policies before they are enacted. ${ }^{39}$ It is

38 They may still, of course, abuse their legitimate scope of discretion to interpret the law in such a way as to commit a violation of human rights. For an example of this see the approach of the European Court of Justice in Case 29/69 Stauder v Ulm [1969] ECR 419, where the CJEU found that the potential violation of human rights standards was not inherent in EC law, and was rather a result of the way that Germany had chosen to implement it.

39 See eg Report of the Counter-Terrorism Committee to the Security Council for its consideration as part of its comprehensive review of the Counter-Terrorism Committee Executive Directorate (18 December 2006) annexed to UN Doc S/2006/989; Policy Guidance Regarding Human Rights at the CTC, UN Doc A/AC.40/2006/PG.2, adopted 25 May 2006. For the disappointed reaction of the UN's Special Rapporteur see para 24 of the Report of the Special Rapporteur on the promotion and protection of human rights and fundamental freedoms while countering terrorism (21 November 2007) UN Doc A/HRC/6/17, In contrast the Security Council Committee established pursuant to resolution 1267 (1999) concerning Al-Qaida and the Taliban

\section{CAMBridge JOURNALS}


true that a substantial human rights infrastructure exists at the UN, having evolved since the organization's creation, but its role is predominantly to ensure that States - rather than the UN itself - collaborate in the creation of, and giving effect to, human rights guarantees. ${ }^{40}$ Were it possible to harness the expertise of the High Commission for Human Rights to assess the compatibility of proposals for UN action with human rights guarantees, this could significantly reduce the potential for decisions stemming from the UN to conflict with Member States' human rights obligations. There is already a precedent for this within another IGO, the European Union, which is discussed below. ${ }^{41}$

\section{B. Ex Post Facto Check}

Similarly, ex post facto oversight is decidedly piecemeal and weak. The 'Special Procedures' operating under the UN Charter permit an independent expert to monitor human rights violations according to theme or country, and they have included UN administered territories within their enquiries, ${ }^{42}$ as well as UN peacekeeping missions. ${ }^{43}$ However, this avenue is not geared towards individualized or enforceable remedies. ${ }^{44}$ Exceptionally, the UN

and Associated Individuals and Entities (which is responsible for maintaining the list of organizations and individuals against whom sanctions may be taken) is under no such obligation. See for instance this committee's report for activity in 2007 (UN Doc S/2008/25, adopted 17 January 2008) where there was no mention at all of rights issues. There has been occasional engagement of the CTC by human rights treaty bodies, eg http://www.un.org/News/Press/docs/2003/ hrct630.doc.htm, accessed 16 December 2010.

40 The organs and offices now principally responsible for this within the UN are the Human Rights Council and the Office of the High Commissioner for Human Rights. See http:// www.ohchr.org/EN/Pages/WelcomePage.aspx; and http://www2.ohchr.org/english/bodies/ hrcouncil/, accessed 16 December 2010.

41 See the policy of the Commission in conducting 'impact assessments' of proposed legislation in ensuring compatibility with the EU's Charter of Fundamental Rights: Commission Communication 'Compliance with the Charter of Fundamental Rights in Commission legislative proposals. Methodology for systematic and rigorous monitoring' COM(2005) 172 final (27 April 2005) and 'Report on the Practical Operation of the Methodology for a Systematic and Rigorous Monitoring of Compliance with the Charter of Fundamental Rights'. COM(2009) 205 (29 April 2009). The Fundamental Rights Agency (FRA) may also be consulted by the EU Institutions when law-making in order to verify compliance with human rights of legislative proposals. However, it is a right, rather than an obligation, to consult the FRA in this respect, and the FRA may only offer its opinions on legislative proposals to the institutions at their request. See Regulation 168/2007/EC OJ L 53, (22 February 2007) 1. On the role of National Human Rights Institutions see the 'Paris Principles' adopted by UNGA Res 48/134, 20 December 1993 ('Principles relating to the status of national institutions').

42 See eg Report of the Special Representative of the Secretary-General on the situation of human rights defenders, Mission to Serbia, including Kosovo (29 February 2008) UN Doc A/HRC/7/28/Add.2.

43 See eg paras 47-54 of the Report of the Special Rapporteur on violence against women, its causes and consequences, Mission to the Democratic Republic of the Congo (28 February 2008) UN Doc A/HRC/7/6/Add.4. A Code of Conduct regulates the behaviour of peacekeepers who may be investigated and disciplined.

44 See Butler (n 1) 114-123. 
human rights treaty bodies have also allowed the UN to report on human rights in territories under their administration despite not being party to the given treaty. $^{45}$

These examples of supervision of the UN according to international human rights standards is remarkable in a sense since, as noted, the human rights machinery of the UN is geared towards its Member States. But at the same time, the example is of limited significance, because it relates to a situation where an IGO is substituting or supplementing a State as administrator of a territory, which is necessarily exceptional and temporary. Of greater concern here is the existence of a control over the law-making and decision-taking functions of the UN. In this situation one could envisage at least two possibilities: one, that the conduct of the IGO itself might be reviewed by a competent judicial body; the other that Member States' conduct remains subject to review, even when executing obligations deriving from membership of an IGO. The first possibility will be discussed through the example of the International Court of Justice (ICJ) as a judicial body competent to review conduct of the UN itself. The second possibility will contemplate the approach of the European Court of Human Rights (ECtHR) to the relative weight of the European Convention on Human Rights (ECHR) vis-à-vis States parties' obligations under the TFEU. These will now be discussed in turn.

\section{The ICJ and the UN}

Given the status of the UN Charter relative to other treaties, it is pertinent to consider how the ICJ, as the UN's principal judicial organ, might exercise an ex post facto check on the legality of UN action according to human rights standards. The following discussion will explore the form that such a review might assume.

The ICJ may be requested to deliver both (non-binding) advisory opinions and decisions (binding as between the parties) on contentious cases. The ICJ may only be seized of contentious cases by a State, though certain organs and associated organizations of the UN are also eligible to request advisory opinions. ${ }^{46}$ Considering that it is individual victims or those representing their interests (such as non-governmental organizations) who have the most interest in bringing violating States to account, this significantly reduces the ICJ's potential to supervise compliance with human rights obligations. ${ }^{47}$ This is

45 See for instance the agreement of Serbia and UNMIK to allow UNMIK to make reports to the Human Rights Committee relating to the territory of Kosovo. See Concluding Observations on Serbia, CCPR/CO/81/SEMO (12 August 2004); Concluding Observations on the report on Kosovo (Serbia) submitted by the United Nations Interim Administration Mission in Kosovo, para 4. See UN HRC Report 2005/2006, Vol I, A/61/40, 68.

46 Statute of the International Court of Justice, arts 59 and 65.

47 While a State's responsibility for human rights violations extends to all those within its jurisdiction (thus not discriminating between nationals and non-nationals), the majority of those 
especially true considering that the principle of diplomatic protection (through which a State may demand reparation for harm it suffers through the violation of the rights of a national) can only be exercised by the State of which the individual is a national. ${ }^{48}$ The unfortunate consequence of this situation is that the prime potential violator of the right happens to be the only State in a position to call the violator (itself) to account before the ICJ.

Aside from the fact that access to the Court is so limited, one should bear in mind that there is no certainty regarding the response of the ICJ, should it be asked to resolve a clash between a State's obligations to execute a Security Council (SC) resolution adopted under Chapter VII, and a State's other international commitments. The Lockerbie case shows that the Court is in principle prepared to take jurisdiction in such a dispute. ${ }^{49}$ That is, the Court does not consider that its jurisdiction is excluded simply because the dispute involves adjudication on the legal weight of a SC resolution. This could imply that the Court is at least prepared to contemplate that SC resolutions may be declared invalid. However, no case has yet reached the Court directly on this issue on the merits.

The Lockerbie case related to the matter of a clash between Libya's obligations under the UN Charter and a separate treaty (the Montreal Convention for the Suppression of Unlawful Acts against the Safety of Civil Aviation). The hypothetical dispute under discussion here could be couched similarly as a conflict with a State's obligations under a human rights treaty (either adopted in the context of the UN, or at the regional level). In this situation a literal reading of the wording of articles 25 and 103 of the Charter would dictate that Charter-derived obligations, including $\mathrm{SC}$ resolutions, would take priority over any other agreement. This, for instance, would appear to be the approach of the (then) UK House of Lords in the Al-Jedda case, where it considered the applicability of the ECHR (via the Human Rights Act 1998) to the situation of multi-national forces in Iraq acting under authorization of Chapter VII of the

within a State's jurisdiction tend to be its nationals. Thus the potential pool of 'victims' is composed predominantly of nationals.

48 Mavrommatis Palestine Concessions PCIJ Series A, No. 2 (1924), 1, 12. See also Panevezys-Saldutiskis Railway, PCIJ Series A/B, No. 76 (1939) 1, 16. Similarly Nottebohm (Second Phase) [1955] ICJ Rep 4, 24; Barcelona Traction, Light and Power Co Ltd case [1970] ICJ Rep 344 . Of course, if one considers human rights rules to be erga omnes in nature, then any other State could demand their fulfilment. However, this depends upon the willingness of a foreign government to make such a demand. The fact that the inter-state procedure under the International Covenant on Civil and Political Rights has never been used serves as an illustration of how unsatisfactory reliance upon this proves. See UN Human Rights Committee General Comment 31, 'The Nature of the General Legal Obligation Imposed on States Parties to the Covenant', CCPR/C/21/Rev.1/Add. 13 (26 May 2004).

49 Questions of Interpretation and Application of the 1971 Montreal Convention arising from the Aerial Incident at Lockerbie (Libyan Arab Jamahiriya v UK) Preliminary Objections [1998] ICJ Rep 9; Questions of Interpretation and Application of the 1971 Montreal Convention arising from the Aerial Incident at Lockerbie (Libyan Arab Jamahiriya v USA) Preliminary Objections (27 February 1998) [1998] ICJ Rep 115. 
UN Charter. ${ }^{50}$ The majority of the Lords found that where the UN had authorized the use of force by States members, which retained autonomous command and control (as opposed to forces donated by governments but under the control of the $\mathrm{UN}$ ) it was possible to engage the responsibility of the State because the relevant conduct could not be attributed to the UN. Having determined that there was indeed jurisdiction to apply the ECHR the House of Lords was able then to examine the relationship between the ECHR and the UN Charter, in particular the rule in article 103 of the UN Charter which specifies that '[i]n the event of a conflict between the obligations of the Members of the United Nations under the present Charter and their obligations under any other international agreement, their obligations under the present Charter shall prevail.' Lord Bingham's analysis, with which the other Lords agreed, maintained that article 103 must require precedence to be given to obligations flowing from the UN Charter where these conflict with the ECHR - including the SC resolutions in question that required the occupying forces to maintain stability within Iraq. ${ }^{51}$

Thus, the Al-Jedda case supports the relationship between the Charter and other treaties - including human rights treaties - as hierarchical and exclusive. Where UN-derived obligations conflict with human rights obligations, the Charter will prevail. If the ICJ were to follow this approach it would seem to exclude the possibility of human rights review at the point of origin. That is, this conception of the 'international constitutional' approach seems to exclude and ignore the possibility that human rights - or any other type of international obligation (save, one might assume, a rule of jus cogens) - should form an integral and inherent part of rules stemming from the UN. The only test applied, implicitly, is a procedural one: has the rule been adopted by the UN?

However, this does not necessarily mean that it is not possible to envisage some kind of human rights review of UN action by the ICJ at the UN level. Article 1 of the Charter states the UN's 'purposes' to be to 'maintain international peace and security' as well as to 'achieve international co-operation in... promoting and encouraging respect for human rights and for fundamental freedoms for all'. This latter reference to human rights should not be underestimated. The Charter refers to human rights at eight points, and the UN and its Member States both have adopted a wealth of soft and hard law elaborating and urging compliance with human rights standards. ${ }^{52}$

${ }^{50} R$ (on the application of Al-Jedda) (FC) (Appellant) v Secretary of State for Defence (Respondent) 12/12/07, [2007] UKHL 58.

51 Lord Bingham, para 34; Lord Rodger, para 118; Baroness Hale, paras 125-126; Lord Carswell, para 136; Lord Brown, para 152.

52 Preamble, para 2 and arts $1(3), 13(1)(b), 55,56,62(2)$ and 68 . Art 76 relating to the Trusteeship system is now obsolete. See Butler (n 1) ch 3.

\section{CAMBRIDGE}


The Universal Declaration of Human Rights (UDHR) has been treated by the UN General Assembly as binding upon all its members - effectively as the authoritative interpretation of the Charter's references to human rights (see further below). In addition, every State in the world is party to at least one human rights treaty elaborated and adopted in the context of the UN. ${ }^{53}$

Regrettably, Lord Bingham's analysis seemed to prioritize the UN's aim of maintaining international peace and security over that of promoting and encouraging the protection of human rights. This was expressly stated, but the provisions relating to human rights were noted and then duly forgotten in the consideration of provisions relating to peace and security. ${ }^{54}$ It is unfortunate that these differing purposes of the UN were treated as competing goals, with priority accorded to the maintenance of international peace and security. Rather, it is entirely plausible to suggest that as one of the purposes of the UN, the promotion and protection of human rights should of itself be a condition of the legality of any UN action. Indeed, how could one envisage an organization having the power to act contrary to its own stated objectives? A reading of the Charter would plainly support this since article 24(2) states that 'the Security Council shall act in accordance with the Purposes and Principles of the United Nations'. Thus, obligations stemming from the UN should be required to conform to human rights standards by the Charter itself. In this case one is not forced to argue that human rights standards must be seen as an exception to article 103 of the Charter, and the supremacy of UN-derived obligations is maintained. Rather the point is one of internal consistency, or ensuring simply that the organization itself acts intra vires. ${ }^{55}$ The argument is not so farfetched and seems to have been contemplated by the European Union's Court of First Instance, or the General Court (GC), in the cases of Yusuf and Kadi, which examined the validity of EU legislation adopted to execute Security Council resolutions requiring certain sanctions to be taken against individuals

\footnotetext{
53 The USA and Somalia are the only two States not to have ratified the UN Convention on the Rights of the Child but both are party to other UN-sponsored human rights treaties. See 'Multilateral Treaties Deposited with the Secretary-General' (ST/LEG/SER/E/19), or http:// treaties.un.org/Pages/ViewDetails.aspx?src=TREATY\&mtdsg_no=IV-11\&chapter=4\&lang=en, accessed 16 December 2010.

54 Al-Jedda, paras 28-30, with which the other Lords agreed: Lord Rodger, paras 114-115; Baroness Hale, para 129; Lord Carswell, para 131; Lord Brown, para 152.

55 It seems to be generally accepted that this is possible, at least in theory. See eg D Bowett, 'The Impact of Security Council Decisions on Dispute Settlement Procedures' (1994) 5 EJIL 5, 92-93; S Shubber 'The Destruction of Aircraft in Flight over Scotland and Niger: the Questions of Jurisdiction and Extradition under International Law' (1995) 66 British Yearbook of International Law 239, 268-277; F Morgenstern, 'Legality in International Organizations' (1976-77) 44 British Yearbook of International Law 241; E de Wet The Chapter VII Powers of the United Nations Security Council' (Hart, Oxford, 2004) ch 3; ND White, The Law of International Organisations ( $2^{\text {nd }}$ edn, Juris, Manchester, 2005) 102-107. HG Schermers and NM Blokker, 'International Institutional Law' $\left(4^{\text {th }}\right.$ edn, Martinus Nijhoff, 2003) $\$ \$ 206-208$. As noted, the idea was certainly not excluded by the ICJ in the Lockerbie case and is in fact firmly established within EU law (see eg art 263 TFEU).
} 
suspected of involvement with terrorism. ${ }^{56}$ After considering articles 1 and 24 of the Charter the GC noted that:

The Security Council's powers of sanction in the exercise of that responsibility [to maintain international peace and security] must therefore be wielded in compliance with international law, particularly with the purposes and principles of the United Nations. ${ }^{57}$

Ultimately, the GC did not review the validity of the Security Council resolutions themselves in view of the UN Charter's own commitment to human rights, but rather chose other grounds (discussed below). Nonetheless, the observation remains pertinent, in that the UN-and any other IGO — should ensure that the decisions it makes are consistent with its own internal rules. This leads on to the question: what source of law could be applied in order to check compliance with human rights standards under an 'international constitutional' approach?

As noted, the GC declined to review the EU legislation implementing the contested SC Resolution on the basis that this would involve indirect review of the SC Resolution itself which was not possible since that Resolution was to take precedence over all other law by virtue of article 103 of the UN Charter. Instead of testing the consistency of UN action by reference to the UN Charter's human rights provisions the GC resorted to the concept of jus cogens which, as noted above, it considered to be 'a body of higher rules of public international law binding on all subjects of international law, including the bodies of the United Nations, and from which no derogation is possible'. ${ }^{58}$ In contrast to the House of Lords in Al-Jedda (as well as the approach of the ECtHR discussed below) the GC prioritized human rights standards above the other purposes and principles of the UN as part of the body of jus cogens rules in international law. ${ }^{59}$ However, as noted, the body of jus cogens rules in international law is uncertain in scope and most probably cannot be described as encompassing the entire range of human rights guarantees contained in the UDHR and principal UN-sponsored human rights treaties. ${ }^{60}$ However, in an effort to avoid expressly reviewing the legality of UN action the GC seemed to conclude that human rights standards as embodied in UN human rights law all formed part of the body of jus cogens. ${ }^{61}$ Such an interpretation of international law - unsupported as it was by rigorous discussion and analysis - might not be considered entirely compelling. It is submitted here that given the problems 1390.

56 In particular Security Council Resolution 1390, adopted 16 January 2002, UN Doc S/RES/

57 Cases T-315/01 Kadi v Council and Commission (21 September 2005) paras 228-229 and T-306/01 Yusuf and Al Barakaat International Foundation $v$ Council and Commission (21 September 2005) paras 279-280.

${ }_{58}$ GC Kadi para 226; Yusuf para 277. $\quad{ }^{59}$ GC Kadi para 228 Yusuf para 279.

60 For a discussion of different opinions relating to which human rights may or may not be counted among the body of jus cogens norms see Orakhelashvili (n 19) 53-60.

${ }^{61}$ GC Kadi paras $234 \mathrm{ff}$; Yusuf paras $285 \mathrm{ff}$. 
associated with identifying rules of jus cogens status, the GC should have simply resorted to reviewing the SC resolution by routing the source of these obligations within the Charter itself. While stating that the promotion of human rights is one of the purposes of the UN, the Charter itself does not explain what the term 'human rights' actually means. However, it is argued that at the very least the UDHR and probably also the 'core' UN human rights treaties should be considered as the authoritative interpretation of the Charter's reference to human rights, since it is these instruments to which the UN General Assembly consistently refers when addressing its Member States. ${ }^{62}$ The following wording appears in numerous GA Resolutions:

[A]11 Member States have an obligation to promote and protect human rights and fundamental freedoms as stated in the Charter of the United Nations and elaborated in the Universal Declaration of Human Rights, the International Covenants on Human Rights and other applicable human rights instruments. ${ }^{63}$

Thus, while rules of jus cogens status constitute an unarguable limit on the powers of the UN to act in violation of human rights standards, the more comprehensive and consistently applied standards that have evolved from the UN Charter certainly make for a clearer source of law for the judicial review of its own exercise of powers.

For as long as there is no a priori check on the human rights compatibility of decisions emerging from the UN, there is a danger that States and regional IGOs may feel obliged to implement UN-derived obligations, even where these conflict with human rights standards by virtue of article 103 of the Charter. Conceptually, one can preserve the hierarchy intended by article 103 if one considers that $\mathrm{UN}$ action, in order to be intra vires, must comply with its own human rights standards. Alternatively, one could resort to jus cogens as superior even to the Charter itself. As noted, the concept of jus cogens is too uncertain and too narrow to encompass the range of human rights guarantees that have evolved at the international level. ${ }^{64}$ It would therefore make sense to

62 See Butler (n 1) 41-55.

63 See eg GA Resolutions relating to Cuba: 47/139, 18/12/92; 48/142, 20/12/93; 49/200, 23 / $12 / 94 ; 50 / 198,22 / 12 / 95 ; 51 / 113,12 / 12 / 96 ; 52 / 143,6 / 3 / 98$; GA Resolutions relating to Myanmar: 16/132, 17/12/91; 47/144, 18/12/92; 48/150, 20/12/93; 49/197, 23/12/94; 50/194, 22/12/95; 51/ $117,12 / 12 / 96 ; 52 / 137,3 / 3 / 98 ; 53 / 162,25 / 2 / 99 ; 54 / 186,29 / 2 / 00 ; 55 / 112,1 / 3 / 01 ; 56 / 231,28 / 2 / 02$. For detailed discussion of how the UDHR has been used by the GA, as well as the recognition it has been accorded by the ICJ see Butler (n 1) 37-55.

64 Weiler and Paulus (n 16) 559 write: '[W]e can discern problems of this, apparently easy and indisputable, positivist confirmation of international law hierarchies. There is, firstly, the indeterminate contents of jus cogens - which gives rise to the suspicion that either jus cogens norms are so indisputable that codification adds nothing to their quality, or so disputed that they never meet the criteria for their creation, namely the acceptance and recognition as peremptory norms 'by the international community of States as a whole'. And, secondly, the treaty mode of the creation of sub norms leaves the question open of whether they are binding on those who resist them and have not become parties to the relevant Convention'. 
opt for review of action according to the Charter itself, rather than this external source of law.

An obvious problem that arises here is that, while this solution could provide an answer for the UN, it does little for other IGOs. International law does not exist according to a 'Russian doll' model, in that other IGOs do not automatically form part of a sub-set of the UN. Even if it is possible to guarantee the priority of human rights at the UN, what of all the other IGOs with considerable powers whose constitutive instruments do not give human rights a privileged position? For instance, the considerable damage done to human rights by the policies of the IMF, World Bank or World Trade Organisation is not inconsistent with their own respective constitutional documents. ${ }^{65}$ Many IGOs may claim that their areas of competence do not coincide with that of the UN, and therefore they should not be subordinated to the Charter's human rights provisions. What governments and IGOs themselves must recognize - much like the EU four decades ago ${ }^{66}$ - is that human rights may be damaged by powers exercised in any policy context, even if the aims and purposes of the IGO seem to be, superficially, unrelated. ${ }^{67}$ This makes some commitment to guarantee these rights necessary. Furthermore, even if these organizations were to amend their founding instruments to incorporate the need to preserve consistency with human rights guarantees (which would be no easy task), what forum would individual victims have to ensure an ex post facto review? One possibility might be to create a 'world court' of human rights which has compulsory jurisdiction over all legal persons, including IGOs, and applies those human rights standards that flow from the UN Charter. ${ }^{68}$ Alternatives might include establishing monitoring mechanisms internal to the IGO or adherence to UN-sponsored human rights treaties and submitting to supervision by already existing UN organs. ${ }^{69} \mathrm{~A}$ further possibility - one which is perhaps more realistic - is to hope for a 'parochial' approach to international law, which is discussed further below. That is, to encourage regional or national courts to review the validity of any

65 S Skogly, The Human Rights Obligations of the World Bank and the IMF (Cavendish, London, 2001); M Darrow, Between Light and Shadow: the World Bank, the International Monetary Fund and International Human Rights Law (Hart, Oxford, 2006); Alston (n 3).

${ }^{66}$ Case 29/69 Stauder $v$ City of Ulm [1969] ECR 419; Case 11/70, Internationale Handelsgesellschaft v Einfuhr- und Vorratsstelle Getreide [1970] ECR 1125.

${ }^{67}$ On the issue of coordination and priority between IGOs see Schermers and Blokker (n 55) $\S \S 1702-1712$; F Morgenstern, Legal Problems of International Organisations (Grotius Publications, Cambridge, 1986) 26-31.

68 See eg M Nowak, 'The Need for a World Court of Human Rights' (2007) 7 Human Rights Law Review 1, 251.

69 This may be a challenge given that in the past the UN has not even been able to persuade members of its own 'family' to follow its approach to human rights. See Morgenstern (n 67) 2829 on the negative response of the World Bank to requests by the UN regarding the denial of assistance to certain regimes during the decolonization period, despite continued UNGA resolutions calling for States to refuse such cooperation.

\section{CAMbridge JOURNALS}


'higher' laws implemented within their jurisdiction for compliance with human rights standards.

\section{The European Court of Human Rights, the EU and the UN}

No specialized human rights supervisory mechanism has jurisdiction to hear an action brought directly against any IGO, because (currently) the major human rights treaties are only open to States. ${ }^{70}$ It remains possible, however, to maintain the accountability of States for violations they may commit while executing their obligations arising from membership of an IGO. While no dispute seems to have yet arisen in a contentious case before the UN treaty bodies, the ECtHR has had to decide upon several such cases, which makes examination of its approach particularly pertinent.

It should be borne in mind that in this context, despite belonging to a regional IGO (the Council of Europe), the ECtHR plays a shared role with national courts in determining the conditions of entry into the domestic system of international obligations. Cases reaching the ECtHR will relate to international obligations that have been allowed to penetrate national jurisdictions by national courts, in order to generate a complaint at the national level. ${ }^{71}$ As such it is not the role of the ECtHR to determine directly whether national courts should permit the entry of international obligations. Rather, the ECtHR is tasked with answering what weight these obligations should have vis-à-vis the ECHR within national jurisdictions. ${ }^{72}$

When faced with a conflict between local human rights standards and obligations deriving from a State's membership of an IGO, the ECtHR has offered different responses. The ECtHR has gauged its response depending upon the institutional arrangement at issue in the particular case. It has been willing to follow an 'international constitutional' approach, where it believes the IGO

\footnotetext{
70 The EU's courts do provide for supervision of human rights compliance by the EU and the Member States when executing EU law by reference to internal human rights standards. See further below. Exceptionally for a UN instrument the Disabilities Convention allows for membership 'regional integration organizations'. Additionally, several Council of Europe treaties relating to particular aspects of human rights protection also permit adherence by the EU. Eg the Council of Europe Convention on Action against Trafficking in Human Beings, CETS 197; the Council of Europe Convention on the Protection of Children against Sexual Exploitation and Sexual Abuse, CETS 201. According to Protocol 14bis to the ECHR and Article 6(2) of the Treaty on European Union (as amended by the Lisbon Treaty) the EU will become party to the ECHR. See Consolidated versions of the Treaty on European Union and the Treaty on the Functioning of the European Union, Council of the European Union, Brussels, 20 April 2009, 6655/1/08 Rev. 1 and Protocol Nol. 14bis to the Convention for the Protection of Human Rights and Fundamental Freedoms CETS No: 204, 27/5/2009.

${ }^{71}$ ECHR art 35(1) requires that domestic remedies must be exhausted before the ECtHR can take jurisdiction.

${ }^{72}$ The term 'jurisdiction' is used here since it is wider than 'territory' because States may remain responsible for their obligations under the Convention even outside their territory where they are taken to have jurisdiction, such as in the cases relating to Kosovo and Iraq, discussed below.
} 
in question has adequate internal human rights guarantees, and reverted to a 'parochial' approach where this has been lacking. However, there are certain difficulties with its determination of the adequacy of other IGOs' human rights guarantees, as well as its readiness to deny jurisdiction to examine the allegations, where it finds that responsibility for the acts can be attributed to the IGO itself.

\section{Conduct Attributed to a State}

The ECtHR has determined that where national authorities execute obligations incumbent upon them by virtue of obligations flowing from membership of an IGO, the State remains responsible for the acts in question. ${ }^{73}$ The ECtHR has maintained the principle that States cannot simply escape their human rights obligations by delegating powers to an IGO:

The Contracting States' responsibility continues even after they assume international obligations subsequent to the entry into force of the Convention or its Protocols. It would be incompatible with the object and purpose of the Convention if the Contracting States, by assuming such obligations, were automatically absolved from their responsibility under the Convention ... The Court, while attentive of the need to interpret the Convention in such a manner as to allow the States Parties to comply with their international obligations, must nevertheless in each case be satisfied that the measures in issue are compatible with the Convention or its Protocols. ${ }^{74}$

This statement would indicate that the ECtHR is prepared, in principle, to prevent States parties from allowing international commitments to override their human rights obligations. However, the ECtHR has instead conditioned the depth of its review according to arrangements existing within the IGO in question. Where the ECtHR is faced with such a situation, it will first determine whether a right has been interfered with; second, whether this interference was based on law and pursued a legitimate aim; and third, whether the level of interference was proportionate to the aim pursued. If the ECtHR finds that the State's alleged interference with human rights is rooted in obligations deriving from its membership of an IGO, it considers that the State's decision to implement such a rule is of itself a legitimate aim: that of complying with its international obligations. ${ }^{75}$ In order to determine whether pursuit of this legitimate aim was proportionate, the ECtHR has developed a doctrine of

${ }^{73}$ ECtHR, Case of Bosphorus Hava Yollari Turizm Ve Ticaret Anonim Sirketi v Ireland, Application No 45036/98, (30 June 2006) para 137.

${ }_{74}$ ECtHR, Case of Capital Bank Ad v Bulgaria Application No 49429/99 (24 November 2005) para 111.

75 One might question whether inter-State cooperation should be classed as a 'legitimate aim' given that it is fundamentally different in nature from the other accepted legitimate aims. Traditionally legitimate aims have always been considered to be rooted in the needs of society such as public safety, health, morality, and the rights of others. (See eg art 8 ECHR or art 29 of the Universal Declaration of Human Rights.) These can hardly be equated with the compromises

\section{CAMBridge JOURNALS}


'equivalent' protection. According to this approach, set out in the Bosphorous case, an interference with human rights will be presumed to be proportionate ${ }^{76}$ if the State has ensured that the IGO in question disposes of a system of 'equivalent' or 'comparable' protection of their human rights obligations derived from the ECHR. ${ }^{77}$ Such a presumption may be rebutted on evidence that the protection was in fact 'manifestly deficient'. ${ }^{78}$ Accordingly, where the ECtHR finds that a State has provided for a system of comparable or equivalent protection of human rights within the IGO that the State is 'blaming' for the particular interference, the ECtHR will not consider the interference in question on its merits. ${ }^{79}$

This is not of itself a negative approach. Indeed, it can be seen as a living example of an 'international constitutional' model because the ECtHR's deference to a State's compliance with IGO-derived obligations depends on the guarantee of human rights within that particular organization. Where that organization is considered to have adequate internal human rights checks the ECtHR is prepared to indicate to national jurisdictions that they should allow these obligations to enter their legal systems without restriction. However, the difficulty lies in the ECtHR's view of what constitutes equivalent or comparable protection. Indeed this constitutes the danger inherent in the 'international constitutional' model.

The ECtHR has developed its approach in this area through cases relating to the EU, where it was satisfied - at least as regards those parts of EU activity permitting review by the CJEU-that human rights protection is indeed adequate. ${ }^{80}$ It is true that the CJEU's supervision of EU law and its application by the institutions and EU Member States includes ensuring compliance with the 'general principles of community law' developed by the Court. Among the general principles one can find substantive human rights as inspired by the ECHR. ${ }^{81}$ The ECtHR found that while direct access for individuals to the CJEU under article 230 of the EC Treaty (the action for annulment of Community measures, now article 263 TFEU) was highly restricted, the existence of other remedies (the preliminary reference procedure under article 234 (now

reached in the context of inter-State cooperation between government officials (many of whom have no democratic mandate).

77 ibid 155.

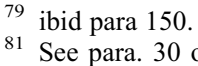

${ }^{76}$ Bosphorus (n 72) para 156.

${ }^{78}$ Bosphorus para 156.

80 ibid para 165 . 4685: 'A feature of [the] ... case-law [of the CJEU] is that it does not confer direct effect in the Community legal order on the provisions of ... international treaties but regards those treaties, together with the constitutional traditions common to the Member States, as helping to determine the content of the general principles of Community law.' Similarly, AG Slynn has noted that 'the Convention provides guidelines for the Court in laying down those fundamental rules of law which are part of Community law, though the Convention does not bind, and is not part of the law of, the Community as such'. See Cases 60-61/84 Cinéthèque SA and Others v Fédération Nationale des Cinémas Francais [1986] 1 CMLR 365, at 379. The GC made this express in Case T-347/94 Mayr-Melnhof Kartongesellschaft mbH v Commission [1998] ECR II-1751, para 311; Case T-112/98 Mannesmannrohren-Werke v Commission [2001] ECR II-729, para 59. 
article 267 TFEU) and the actions for damages in tort under articles 235 and 288 (now articles 268 and 340 TFEU) was found to compensate for this. ${ }^{82}$ While it beyond the scope of this article to conduct a detailed analysis of this finding, brief observations on the ECtHR's analysis should be made.

Firstly, the standing of individuals under article 263 TFEU is such that claimants may effectively only succeed where they are specifically targeted by a Community measure, which makes challenging general legislative measures virtually impossible. ${ }^{83}$ Secondly, while a preliminary reference by a national court to the CJEU for an interpretation of EC law allows the CJEU the opportunity to review Community legislation (under article 277 TFEU) the decision to make the referral and the parameters of the enquiry rest not with the individual parties to the case but with the national court itself. ${ }^{84}$ Further, only courts of last instance are obliged to make such a reference and even then they may choose not to refer (with little consequence) where they believe the interpretation to be given to the rule of Community law is clear. ${ }^{85}$ Thirdly, the action for damages in Union law under articles 268 and 340 TFEU does not allow the CJEU to annul any offending legislation and the individual will only succeed where the breach of law is manifest. ${ }^{86}$

This situation creates significant gaps in human rights protection. This much has been recognized by the EU's General Court (GC) which, having reviewed the range of remedies available, concluded 'that the procedures provided for in, on the one hand, Article $234 \mathrm{EC}$ [267 TFEU] and, on the other hand, Article 235 EC [268 TFEU] and ... Article 288 EC [340 TFEU] can no longer be regarded, in the light of Articles 6 and 13 of the ECHR and of Article 47 of the Charter of Fundamental Rights, ${ }^{87}$ as guaranteeing persons the right to an effective remedy enabling them to contest the legality of Community measures of general application which directly affect their legal situation. ${ }^{88}$ Given that there is doubt among the judicial institutions of the EU

82 The CJEU refers to this as the 'complete system of legal remedies' (see eg Case 50/00 P Unión de Pequeños Agricultores v Council [2002] ECR I-6677, para 40). Art 230 of the EC Treaty is now art 263 of the Treaty on the Functioning of the European Union (TFEU). Art 234 EC is now art 267 TFEU. Art 235 EC and 288 EC are now 268 TFEU and art 340 TFEU. See (n 70).

${ }_{83}$ The basic rules were established in Case 25/62 Plaumann $v$ Commission [1963] ECR 61.

${ }^{84}$ C-283/81 CILFIT [1982] ECR 3415 (para. 7): 'Article 177 [later Article 234 and now Article 267 TFEU] does not constitute a means of redress available to the parties to a case pending before a national court or tribunal. Therefore the mere fact that a party contends that the dispute gives rise to a question concerning the interpretation of community law does not mean that the court or tribunal concerned is compelled to consider that a question has been raised within the meaning of Article 177.' Although standing under 263 TFEU has been widened by the Treaty of Lisbon, it remains fairly narrow.

85 See C-224/01 Köbler [2003] ECR I-10239. Compare Case C-73/03 Traghetti del Mediterraneo [2006] ECR I-5177 paras 24-46.

${ }^{86}$ See Case 175/84 Krohn v Commission [1986] ECR 753 and Case T-47/02 ECR [2006] II-1779 Danzer $v$ Council.

${ }_{87}$ These provisions set out the right to a fair trial and to a remedy.

${ }^{88}$ Case T-177/01 Jégo-Quéré v Commission [2002] ECR II-2365, para 47. The GC's attempt to widen the rules relating to standing under art 230 of the EC Treaty was reversed by the CJEU 
itself, it seems difficult to understand how the ECtHR could comfortably conclude that the system of remedies within the EU can form a comparable system of protection to that of the ECHR. ${ }^{89}$

Nevertheless, the ECtHR has displayed the potential for flexibility in its approach. In the earlier case of Matthews $v U K$, it did choose to examine the substance of a rule of EU law concerning elections to the European Parliament in Gibraltar. The rules being challenged by the claimant in Matthews were contained in a treaty agreed between the foreign ministers of the EU Member States outside the regular law-making process of the EU (the so-called '1976 Act') and the Maastricht treaty itself, amending the EC Treaty. ${ }^{90}$ In contrast, the rule in Bosphorus stemmed from internal EU legislation. The Court in Bosphorus (where it first set out it test of equivalent or comparable protection) distinguished this case on the grounds that the UK's responsibility stemmed from 'international instruments which were freely entered into'. ${ }^{91}$ It seems that the ECtHR is making a distinction on the grounds of the immediacy or remoteness of State consent, leading to the violation: where the violation stems directly from a treaty this will be directly reviewable, whereas where the violation stems from the exercise of powers delegated to the institutions of the EU, this will engage the weaker level of review. ${ }^{92}$ Thus by choosing to

which pointed out that such an alteration would require an amendment to the treaty. Case C-263/ 02 P, Commission v Jégo-Quéré [2004] I-3425, para 31. See also the Opinion of Advocate General Jacobs (when the case was appealed) 10/7/03 in Case C-263/02 P Jégo-Quéré, para 43: 'I find highly problematic the strict test of standing currently applicable under the fourth paragraph of Article 230. In my view, that test gives rise to a real risk that individuals will be denied any satisfactory means of challenging before a court of competent jurisdiction the validity of a generally applicable and self-implementing Community measure. It may prove impossible for such individuals to gain access to a national court (which in any event has no competence to rule on validity) ... otherwise than by infringing the law in the expectation that criminal (or other enforcement) proceedings will then be brought against them when the national court may be persuaded to refer to the Court of Justice the issue of the validity of the measure. Besides the various practical disadvantages which may attend the making of a reference in the context of criminal proceedings, such a procedural avenue exposes the individuals in question to an intolerable burden of risk.'

89 For further criticism of the conclusion that the system of remedies at the EU level could provide 'equivalent protection' see C Costello, 'The Bosphorus Ruling of the European Court of Human Rights: Fundamental Rights and Blurred Boundaries in Europe' (2006) 6 Human Rights Law Review 1, 87, 115 ff.

90 ECtHR Matthews v UK, Application No. 24833/94, 18/2/99, para 18.

91 Matthews, para 33 and para 157 of the Bosphorus case.

92 Perhaps this can be explained on the grounds of the degree of control exercised by individual EU Member States. The principle of pacta sunt servanda provides that States will only be bound by those treaties that they enter into and the principle of sovereign equality would leave States free to enter treaties of their choosing. See the Vienna Convention the Law of Treaties, 1969 (1155 UNTS 331) in its Preamble (recognising the principle of 'free consent'), arts 26 ('Every treaty in force is binding upon the parties to it and must be performed by them in good faith') and 34 ('A treaty does not create either obligations or rights for a third State without its consent'). See also the Declaration on Principles of International law concerning Friendly Relations and Cooperation among States in accordance with the Charter of the United Nations, 1970 (GA Resolution 2625 XXV), which among other things reaffirms sovereign equality. 
enter into the Treaty of Maastricht and the 1976 Act, the Member States were directly responsible for the impeached rule concerning elections to the European Parliament. While not expressly articulated by the ECtHR, in a retrospective reading of the cases, Costello points out a further distinction between the two cases: the acts complained of in Matthews were beyond the review of the CJEU because they were not themselves acts of the EU, while the same is not so of the acts complained of in the Bosphorous case. ${ }^{93}$

It is therefore possible to understand these cases to indicate that the ECtHR is prepared to adopt an 'international constitutional' approach by conditioning the depth of its review on the existence of an adequate human rights protection mechanism within the IGO in question. However, where the Court finds that such protection does not exist it is willing to resort to a 'parochial' approach by fully reviewing the disputed act. Such an approach leaves States free to conduct their affairs through IGOs while ensuring that human rights receive protection either at the point of origin (an internal check within the IGO) or, failing this, the point of impact (a check at the national or regional level).

At first glance, the problem for human rights protection might seem perceived rather than real given that, as noted above, most IGOs do not contain any a priori or ex post facto mechanisms for reviewing human rights compatibilities of measures taken. As such, one might expect the ECtHR to react as it did in Matthews, and apply a more thorough review when faced with situations where States parties act in execution of obligations derived from the vast majority of IGOs. However, quite apart from the lack of confidence one might have in the ECtHR's assessment of the equivalence of protection in another IGO, there is a further difficulty: in the Bosphorous case the ECtHR was examining a violation that stemmed not directly from an act of the EU, but from the implementation of that act by a Member State. Thus, it considered that the conduct in question was attributable to that State. Where the ECtHR considers that the act is to be attributed directly to the IGO, it will exercise no review at all. This has the potential to exclude a wide range of situations from supervision.

\section{Conduct Attributed Directly to the IGO}

Disappointingly, the ECtHR has failed to remain steadfast to its statement that 'Contracting States' responsibility [under the ECHR] continues even after they assume international obligations' in an IGO. In the Behrami and Saramati cases the Grand Chamber of the ECtHR found it was unable to take jurisdiction in an application alleging violations committed by UN peacekeeping forces created under Chapter VII of the UN Charter. Guided by the

93 Costello (n 89) 115.

\section{CAMBridge JOURNALS}


Draft Articles on the Responsibility of International Organisations of the International Law Commission, ${ }^{94}$ the ECtHR found that because States had donated troops to serve in forces operating under the command and control of a subsidiary organ of the UN (KFOR and UNMIK) ${ }^{95}$ individual donating States would not remain responsible for their illegal actions. ${ }^{96}$ That is, the conduct in question became attributable to the UN itself rather than the individual States.

The Court's reasoning - similarly to that of the House of Lords in the $A l$ Jedda case $^{97}$ — based itself in great part on its consideration that operations authorized under Chapter VII of the UN Charter are central to the UN's task of maintaining international peace and security, and that holding States to account for the acts of their armed forces under peacekeeping actions would frustrate this aim, by potentially interfering with actions mandated by the Security Council. ${ }^{98}$ The Court played down the fact that among the purposes and principles of the UN is the achievement of international cooperation in promoting and encouraging respect for human rights (UN Charter, article 1(3)), which features alongside maintaining international peace and security in article 1(1) of the Charter. It is submitted that, contrary to the position implied by the ECtHR, the Charter does not create a hierarchy between its purposes and principles giving priority to peace and security. ${ }^{99}$ According to the Charter's preamble, the very reason for charging the UN with the maintenance of international peace and security is that war brings 'untold sorrow to mankind' in the form of human rights violations. Surely, the aim of the UN is not to bring peace as the absence of war, but to bring peace as justice and fairness: integral to this is the protection of human rights.

The ECtHR then, essentially conforms to the approach, discussed above, that the UN Charter must take precedence over other international obligations, including human rights treaties. However, the ECtHR misses the opportunity

94 Report of the International Law Commission, $59^{\text {th }}$ Session (2007), A/62/10, 178-220. Draft Article 5 provides that the 'conduct of an organ of a State or an organ or agent of an international organization that is placed at the disposal of another international organization shall be considered under international law an act of the latter organization if the organization exercises effective control over that conduct.' While not of itself binding this provision of the draft articles has been referred to in pertinent cases as authoritative including, ECtHR Behrami v France and Saramati $v$ France, Germany and Norway Application Nos. 71412/01, 78166/01, 2/5/07, (para 31), as did the UK House of Lords in $R$ (on the application of Al-Jedda) (FC) (Appellant) $v$ Secretary of State for Defence (Respondent) [2007] UKHL 58, (para 5).

95 Behrami and Saramati ibid paras 134-135.

97 See eg Al-Jedda (n 94), judgment of Lord Rodger, paras. 107-120.

98 See ECtHR Grand Chamber decision on admissibility, Behrami and Saramati (n 94) paras 144-152. This reasoning was subsequently applied in several cases relating to KFOR (see ECtHR decisions on admissibility, Kasumaj v Greece, Application No 6974/05, 5/7/07 and Gajic $v$ Germany, Application No 31446/02, 28/8/07) and the UN's High Representative (see ECtHR decisions on admissibility, Kasumaj v Greece Application No 6974/05 (5 July 2007) and Gajic v Germany Application No 31446/02, 28/8/07).

99 Behrami and Saramati (n 94) paras 147-149. 
to apply its own review of the UN to ensure the validity of its actions according to the references to human rights within the Charter, and elaborated by subsequent agreements in extension of the Charter.

The obvious problem with this approach is that, where conduct is attributed directly to an IGO, there is no means of holding the UN-or indeed any other IGO - to account for any violations that are attributed to it, even where these are carried out by the organs of the State. It does seem wrong to allow the UN Security Council carte blanche when there is no satisfactory method for verifying compliance of action authorized under Chapter VII with UN sponsored and endorsed human rights standards. ${ }^{100}$ It is surprising that the ECtHR does not require that the State ensure that the particular IGO provide for a system of comparable human rights protection. Even if the ECtHR accepted that individual national authorities had relinquished control over their forces, one cannot ignore that the act of handing over that control without ensuring adequate safeguards within the UN is arguably of itself a violation of its obligations under the ECHR. While referring to the International Law Commission (ILC) Draft Articles on the issue of attribution, the ECtHR appeared to neglect article 28(1) which states that a

State member of an international organization incurs international responsibility if it circumvents one of its international obligations by providing the organization with competence in relation to that obligation, and the organization commits an act that, if committed by that State, would have constituted a breach of that obligation. ${ }^{101}$

The ILC's commentary on this article states that 'it concerns circumvention by a State of one of its international obligations when it avails itself of the separate legal personality of an international organization of which it is a member. ${ }^{102}$ Arguably this should prevent a total absence of accountability such as that resulting in the Behrami and Saramati cases. That is, where States delegate power to an IGO to command and control forces 'donated' by national authorities they are arguably circumventing their own human rights obligations, and they should therefore be held responsible.

De Wet, in examining the position of the ECtHR as protector of a European public order based on human rights, concluded that 'the line of jurisprudence affirming the ECHR's normatively superior position as a constitutional instrument of European public order in the field of human rights that can outweigh the interest of international cooperation is very

\footnotetext{
100 See above, text accompanying (n 43-45) relating to exceptional cases where the Special Procedures under the Human Rights Council have received complaints relating to the UN's administration of territory.

101 For the current form of the Draft Articles see: Report of the see International Law Commission, 59 ${ }^{\text {th }}$ Session (2007), A/62/10, 178-220.

102 For the commentary on this article Report of the see International Law Commission, $58^{\text {th }}$ Session (2006), A/61/10, 283-286.
} 
prevalent. ${ }^{103}$ The author holds up the ECtHR as a body which adheres predominantly to what would be termed here as a 'parochial' approach. However, the above discussion clearly demonstrates that the ECtHR's approach is rather more split between a 'constitutional' approach and a 'parochial' approach. Where it deems conduct to be attributable to the State party, it is happy to refrain from interference, but only if it is satisfied that the IGO in question adequately regulates human rights internally. This suggests that deference to external international obligations is conditioned upon their respect for human rights and that a 'parochial' approach will be taken where this condition is not satisfied. While this confirms De Wet's opinion, two extremely important caveats must be underlined. Firstly, the verification of other IGOs' human rights guarantees may prove superficial. Secondly, the ECtHR may choose to decline jurisdiction altogether on the basis of how it attributes responsibility for the conduct in question. Where the ECtHR refuses to take jurisdiction at all, it embraces an 'international constitutional' model of international law, minus human rights guarantees, because it provides the national courts with no guidance on how to prioritize the ECHR and other obligations.

The question is how often the ECtHR will lean towards denial of jurisdiction on the basis of attribution of responsibility to an IGO. If the ECtHR in Behrami and Saramati set special store by the fact that it was dealing with the safeguarding of international peace and security by the Security Council then perhaps it may be less ready to deny jurisdiction when faced with (less important) acts performed through other IGOs. Even so, these cases set a dangerous precedent, potentially excluding from review a situation where the State party's organs are deemed to be at the disposal of an IGO, or where the IGO has its own personnel to execute the act. If the ECtHR does not take a sufficiently rigorous stance, then national courts may not feel able to accord local human rights standards the importance they deserve, and this much is evidenced by the House of Lords decision in Al-Jedda, discussed above.

\section{E. An International Constitutional Model in Practice}

In light of the above, how then would an 'international constitutional' model of human rights protection function? It seems that in theory at least, an 'international constitutional' approach to human rights protection is feasible. The UN disposes of the necessary human rights standards and a great deal of machinery which could be oriented towards the performance of ex ante human rights checks on decisions that originate from UN organs. It is suggested that a mechanism be put in place whereby measures taken by UN organs incorporate an impact assessment for the consequences of measures or policies adopted

103 E De Wet, 'The Emergency of International Regional Value Systems as a Manifestation of the Emerging International Constitutional Order' (2006) 19 Leiden Journal of International Law 611. 
for human rights as recognized in the 'core' UN human rights treaties. The methodology for ensuring human rights compliance could involve the mainstreaming of human rights standards into decision-making processes, through the elaboration of guidelines tailored to match the functions of different institutions and agencies, as well as human rights training for policy-makers. Such measures would reduce the possibility of decisions emanating from these bodies that would compel or allow States members to contravene human rights standards. It may also be possible to imagine the Office of the High Commissioner for Human Rights being able to offer a greater pool of human rights specialists, who could themselves be attached to each of the UN's organs and agencies to systematically review policies and work plans. Similar mechanisms should be put in place for all IGOs which, depending upon their size, would need to recruit or externally contract human rights specialists (for example, through NGOs) to systematically advise them on the compatibility of proposed measures with UN human rights standards. A process along these lines has been adopted by the EU's Commission to ensure 'fundamental rights proofing' when drawing up legislative proposals. However the Commission seems to distance itself from the EU's Fundamental Rights Agency in this respect, stating that while it 'can, indeed, harness the expertise of the Agency $\ldots$ it is to be recalled that the scrutiny of conformity of proposals with fundamental rights is not within the mandate of the Agency. ${ }^{104}$

An ex post facto review of measures and policies emanating from IGOs may offer a more straightforward solution. As noted, there exist protection mechanisms both at the UN and regional level capable of dealing with complaints of human rights violations committed by States. It is not beyond imagination to envisage that these mechanisms could themselves be turned to review the actions of IGOs. This could be accomplished simply be requiring all IGOs to become party to the principal UN human rights treaties. Alternatives include establishing a single world human rights court with jurisdiction over all IGOs, States and individuals, or creation of a monitoring system internal to the IGO. With the requisite consent the respective monitoring bodies would then be able to receive individual complaints concerning these IGOs as well as periodic reports detailing measures that they have taken to ensure the implementation of the treaties. This would require amendment of most of these human rights treaties, as currently the UN Disabilities Convention is the only one to envisage membership of an IGO. However, this is a feasible proposition, as can be seen in the context of the Council of Europe where several human rights treaties - including the ECHR - are now open to membership by the EU itself. ${ }^{105}$ Such an approach may also call for an amendment of the

${ }^{104}$ See European Commission, 'Report on the Practical Operation of the Methodology for a Systematic and Rigorous Monitoring of Compliance with the Charter of Fundamental Rights' COM(2009) 205 (29 April 2009) 8.

105 See (n 70). 
founding treaties of the IGOs in question. For instance, the EU was held by the CJEU to lack competence to become party of the ECHR without an amendment to the treaty to this effect (now contained in article 6(3) of the TEU). ${ }^{106}$

As discussed, the UN Charter poses a particular problem because of the perceived status of article 103. As a conceptual issue, it is important, therefore, that any organs which were to become competent to review the actions of the UN would appreciate that $\mathrm{UN}$ decisions must conform to the general purpose of the UN to promote human rights. This would be in line with the stance of the ICJ that article 103 cannot itself preclude review of whether the $\mathrm{UN}$ has acted ultra vires.

If human rights could be protected in such a top-down manner, it would alleviate the dangers outlined in the introduction to this article. That is, States would not be placed in a position where they would have to accord priority to UN obligations which conflict with their existing human rights obligations, because there would be no such conflict from the start. This, however, does not imply that an 'international constitutional' approach is necessarily ideal in practice. The approach of the ECtHR reveals the potential pitfalls if excessive deference is accorded to an IGO considered to provide adequate internal human rights checks. If national or regional courts were to accept an 'international constitutional' model, it follows that the protection provided at the international level must itself prove effective. The ECtHR's questionable assessment of the EU's human rights protection mechanisms, which led it to adopt the 'international constitutional' approach, suggests that it may be desirable to opt for a 'parochial' approach.

\section{THE PAROCHIAL APPROACH}

If the UN Charter is allowed to take precedence over all other treatiesincluding human rights treaties - what guarantee exists that the UN itself will not become the instrument of States in violating the human rights standards it has spent over 50 years supporting and elaborating? As we have seen, this is a real danger given the absence of an adequate a priori or ex post facto check on the human rights compatibility of UN measures. Put more widely, if we give priority to treaties according to chronology or internal 'supremacy clauses', it is likely that policies formulated by IGOs will at some point come into conflict with the human rights obligations of their Member States. Without a set of rules on human rights with which all IGOs must comply - that is, without a human rights-centred constitutional approach to international law-it is left to the courts of regional IGOs or national courts to intercept rules stemming from inter-State arrangements which conflict with human rights standards.

106 Opinion 2/94 (Re the Accession of the Community to the European Human Rights Convention) [1996] ECR I-1759.

\section{CAMBRIDGE}


To an extent, the CJEU and GC perform a role similar to the ECtHR with regard to the EU, in that one of their functions is to ensure the uniform and consistent interpretation of Community law by national courts and authorities. However, the GC and CJEU also play an important part in ensuring that the EU itself acts consistently with its own obligations under the founding treaties and the general principles of EU law developed by the CJEU. This difference from the role of the ECtHR is significant because of the nature of the EU's legal system. The CJEU itself has consistently maintained that the European Community Treaty established a new, self-contained legal order. In particular EU law is superior to national law and-subject to conditions of justiciability - is directly enforceable by the national courts, regardless of the EU Member State's constitutional arrangements for the applicability of international obligations. ${ }^{107}$ This final section will consider the approach of the courts of the EU, which has been consistently 'parochial', and ask if this might have inspired national courts, previously guided by the ECtHR, to take a more robust attitude.

The EU has not traditionally concerned itself with human rights protection and has generally denied that it has the authority to take positive measures in relation to human rights. ${ }^{108}$ The EU's approach to human rights is predominantly inward-looking: the human rights standards that it does apply are said to be rooted in EU law itself rather than international human rights law. For its part, the CJEU has traditionally refused to look beyond the ECHR for guidance on human rights standards, and the CJEU and the Member States themselves have refused to acknowledge that their obligations in relation to human rights extend beyond merely respecting human rights when it takes action, rather than an obligation to use existing powers to promote them. ${ }^{109} \mathrm{It}$ is therefore surprising, although welcome, to note the bold approach of the GC and CJEU in protecting human rights against interference from other IGOs. The principal judgments in this area are the Kadi and Yusuf cases, which relate to EU's ${ }^{110}$ implementation of obligations derived from UN Security Council Resolutions which required States to take measures against the property of individuals named by the SC's Counter-Terrorism Committee as suspected of involvement with terrorism. ${ }^{111}$

107 Case 6/64 Costa v ENEL [1964] ECR 585; Case 26/62 Van Gend en Loos [1963] ECR 3.

108 See T Ahmed and IDJ Butler, 'The European Union and Human Rights: An International Law Perspective' (2006) 17 EJIL 771. Indeed, this author has in the past been far more concerned about the potential damage that the EU could do to human rights rather than its capacity to protect them.

109 See I Butler and De Schutter, 'Binding the EU to International Human Rights Law' (2008) 27 Yearbook of European Law 277, 280-287.

110 In particular Regulation 881/2002 OJ L139/9. The original has been amended many times.

111 In particular, Security Council Resolution 1390, adopted 16 January 2002, UN Doc S/RES/ 1390 (2002). Case T-315/01 Kadi v Council and Commission [2005] ECR II-3649; Case T-306/01 Ali Yusuf and Al Barakaat International Foundation v Council and Commission [2005] ECR II-3533.

\section{CAMBridge JOURNALS}




\section{A. The General Court of the EU}

As discussed above, in the Kadi decision the GC accepted that the EUinsofar as its competences were relevant-was duty-bound to give effect to the Member States' obligations derived from the UN Charter. With reference to article 103 of the UN Charter the GC acknowledged that '[f]rom the standpoint of international law' the UN Charter imposed obligations on the Member States that 'clearly prevail over every other obligation of domestic law or of international treaty law including ... their obligations under the ECHR and ... their obligations under the EC Treaty. ${ }^{112}$ The GC even went so far as to say that the EU itself was bound by the UN Charter 'in the same way as its Member States' ${ }^{113}$ However, the GC also maintained that it was 'not under general international law' that the $\mathrm{EU}$ was required to give effect to obligations deriving from the UN, but rather 'by virtue of the EC Treaty itself,${ }^{114}$ namely article 307 of the European Community Treaty (now article 351 TFEU), ${ }^{115}$ which reads:

The rights and obligations arising from agreements concluded before... the date of their accession, between one or more Member States on the one hand, and one or more third countries on the other, shall not be affected by the provisions of this Treaty ...

To the extent that such agreements are not compatible with this Treaty, the Member State or States concerned shall take all appropriate steps to eliminate the incompatibilities established. Member States shall, where necessary, assist each other to this end and shall, where appropriate, adopt a common attitude.

In the eyes of the GC, article 307 EC preserved Member States' obligations towards third States that originate prior to their membership of the EU which, for all Member States, includes the UN Charter. Thus the GC appears to draw a distinction between the EU's obligation vis-à-vis third States (which is to observe the Charter) and what the EU is obliged to do internally (which is to observe the EC Treaty and the acquis communautaire). Nevertheless, article 307 combined with article 103 of the UN Charter meant that any SC Resolution would take precedence over all obligations deriving from EU law including the protection of fundamental rights secured within EU law by the 'general principles' developed by the CJEU. Ultimately, while the GC declined to review the UN Security Council Resolutions by reference to the Charter, it found that rules of jus cogens relevant to human rights protection would prevail over UN-derived obligations.

\footnotetext{
112 GC Kadi paras 181-183; Yusuf paras 231-233.

113 GC Kadi para 193; Yusuf para 243.

114 GC Kadi paras 186-207; Yusuf paras 235-257.

115 See Consolidated Versions of the Treaty on European Union and of the Treaty Establishing the European Community, OJ C (29 December 2005) 1; art 351 TFEU see (n 70) above.
}

\section{CAMBridge JOURNALS}


The GC then, was prepared to prevent UN-derived obligations from penetrating the EU legal order by reference to a set of rules existing beyond its legal order. However, the GC did not admit that the EU's internal law relating to human rights could apply in the circumstances, given the status of the UN Charter. This is one way that a parochial approach to international law could operate. That is to say, review of an IGO could be carried out by a regional or national court ('from below') by reference to international law itself. Whether that may be by reference to rules of jus cogens, the constitution of the IGO itself (where it contains human rights guarantees), or by according priority in national courts to human rights treaties.

\section{B. The Court of Justice of the EU}

Another means of framing the parochial approach would be to evaluate rules stemming from an IGO according to human rights as incorporated into the internal (regional or national) legal system. This has the advantage that judges applying the law will be more familiar with the standards they are safeguarding and also reflects the idea that ultimate responsibility and capacity to guarantee human rights rests at the national level. ${ }^{116}$ In this vein the CJEU, on appeal from the Kadi case, was prepared to review the pertinent SC Resolutions according to human rights derived from an internal source of law - the general principles of EU law developed by the CJEU.

On appeal from the GC, ${ }^{117}$ the CJEU, despite acknowledging the supremacy in general international law of the UN Charter and obligations deriving from it, ${ }^{118}$ reasserted the traditional stance of the CJEU: that the EU legal order is autonomous vis-à-vis international law. ${ }^{119}$ It further maintained that 'the obligations imposed by an international agreement cannot have the effect of prejudicing the constitutional principles of the EC Treaty, which include the principle that all Community acts must respect fundamental rights' ${ }^{120}$ While maintaining that it had no jurisdiction to pronounce on the validity of the original SC Resolutions, (even in light of rules of jus cogens, unlike the GC) it did have the duty to ensure compliance by the EU with internal human rights standards when implementing these Resolutions. ${ }^{121}$

116 This finds expression, for instance, in the doctrine of the margin of appreciation in ECtHR case-law. See eg Lord Lester, 'Universality versus Subsidiarity: A Reply' [1998] European Human Rights Law Review 73; R St J Macdonald: 'The Margin of Appreciation' in J Macdonald, F Matscher and H Petzold (eds), The European System For The Protection Of Human Rights (Martinus Nijhoff, Leiden, 1993); C Ovey 'The Margin Of Appreciation and Article 8' (1998) 19 Human Rights Law Journal 10; S Prebensen, 'The Margin of Appreciation and Articles 9, 10, and 11 of the Convention' (1998) 19 Human Rights Law Journal 13; J Schokkenbroek, 'The Basis, Nature and Application of the Margin-of-Appreciation Doctrine in the Case-Law of the ECHR' (1998) 19 Human Rights Law Journal 30.

117 Joined Cases C-402/05 P and C-415/05 P Kadi v Council and Commission [2008] ECR I-6351.

119 ibid 282, 317.

120 ibid para 285.

118 CJEU Kadi paras 288, 299, 327.

121 ibid paras 286, 287, 326.

\section{CAMbridge JOURNALS}


The CJEU's interpretation of article 307 is of particular pertinence. As noted above, many IGOs contain 'supremacy clauses' governing the relationship between obligations towards third parties and obligations between the other members under the founding treaty. Article 307 preserves for Member States their pre-existing commitments towards third States. While the GC took article 307, together article 103 of the UN Charter to mean that SC Resolutions penetrated directly into the EU's legal order, the CJEU maintained a clear boundary between the internal and external legal order:

Article 307 EC may in no circumstances permit any challenge to the principles that form part of the very foundations of the Community legal order, one of which is the protection of fundamental rights, including the review by the Community judicature of the lawfulness of Community measures as regards their consistency with those fundamental rights. ${ }^{122}$

Thus, as between themselves, the Member States must ensure observance of EU law, even if they remain obliged otherwise to third States. Advocate General Maduro before the CJEU summed up the 'parochial' approach that the CJEU chose to take maintaining that the

[r]elationship between international law and the Community legal order is governed by the Community legal order itself, and international law can permeate that legal order only under the conditions set by the constitutional principles of the Community. ${ }^{123}$

In this respect it was implicitly accepted by the CJEU-and explicitly accepted by the Advocate General - that Member States may thereby engage their international responsibility towards other UN members by failing to implement the SC Resolutions. ${ }^{124}$ Interestingly, the Advocate General seemed to suggest that the solution to this situation would be a human rights check at the point of origin within the UN-ie an 'international constitutional' approach. In this vein he pointed to the duty of Member States to eliminate incompatibilities between their obligations towards third States and their obligations under EU law in ECT article 307. According to the AG this 'duty requires Member States to exercise their powers and responsibilities in an international organization such as the United Nations in a manner that is compatible with the conditions set by the primary rules and the general principles of Community law. ${ }^{, 25}$ Accordingly, Member States must do everything in their power to prevent the adoption by organs of the UN of decisions that are incompatible with EU law.

\footnotetext{
122 ibid para 304.

123 Opinion of the Advocate General Maduro of 16 January 2008 in Case C-402/05 P Kadiv Council and Commission, para 24.

${ }^{124}$ AG Maduro’s Opinion, paras 30, 39. $\quad 125$ ibid para 32.
} 


\section{The Influence of the CJEU in the UK Courts}

As noted above, in the Al-Jedda case the UK House of Lords chose to follow the lead of the ECtHR in denying the ability to review UN action for compatibility with human rights, either as contained in the ECHR or the UN Charter. However, in cases arising since that judgment, the UK Courts appear to be changing their course, and in part this seems to be a response to the approach of the CJEU. A number of cases have arisen relating to the interpretation of both EC Regulation 881/2002 and the UK Orders in Council, giving effect to the sanctions regime of the Security Council, in particular regarding how strictly the UK government should construe the obligations to deny resources to individuals suspected of terrorism. ${ }^{126}$ In the case of $A$ et al $v$ HM Treasury the Queen's Bench Division quashed two Orders in Council detailing the implementation of SC Resolutions. ${ }^{127}$ The judgment of Justice Collins draws heavily upon the Opinion of Advocate General Maduro (since it was decided before the CJEU delivered its judgment) in the Kadi case and expressed a certain regret in feeling obliged to follow the Al-Jedda precedent in the House of Lords, which accorded priority to SC Resolutions over human rights guarantees. ${ }^{128}$ Nevertheless the Court was able to find that because the legislation contained so many potential threats to human rights, the choice of legislative instrument was defective, in that it failed to allow Parliament the opportunity to debate the implementation of the SC Resolutions in a way that would guarantee the minimum interference possible with human rights. ${ }^{129}$ Thus, while unable to deviate from the stance of the House of Lords, the judgment shows considerable deference for the overall approach of Advocate General Maduro in producing an outcome that maximizes protection for human rights. Furthermore in the case of $R$ (on the application of $M$ ) $v H M$ Treasury and other actions, concerning the interpretation of EC Regulation $881 / 2002$ and an earlier Order in Council giving effect to the sanctions regime $^{130}$ the House of Lords has requested an interpretation of the EC legislation from the CJEU under the preliminary reference procedure. ${ }^{131}$ Taking into account the CJEU's approach to this Regulation in the Kadi case, it may well have occasion to declare parts of the legislation null for failing to secure sufficient human rights guarantees. However, this remains to be seen, since the questions raised in the House of Lords reference concern how to interpret certain provisions relating to access to resources for subsistence purposes,

126 The cases relate to the Al-Qaida and Taliban (United Nations Measures) Order 2002 (SI 2002/111); the Al-Qaida and Taliban (United Nations Measures) Order 2006 (SI 2006/2952); the Terrorism (United Nations Measures) Order 2006 (SI 2006/2657).

127 Judgment of [2008] EWHC 869. The Orders quashed were the 2006 Orders (ibid.).

128 ibid 374-376.

129 ibid 376-380.

130 Al-Qaida and Taliban (United Nations Measures) Order 2002 (SI 2002/111).

131 Case C-340/08 M (FC) et al (Pending) [2008] OJ C 260/8. 
rather than the question of the legality per se of freezing assets, or the inadequacy of fair trial guarantees in the process as a whole. ${ }^{132}$

Significantly, the Orders in Council do not, in the main, purport to implement EU Regulation 881/2002, but are rare domestic implementations of the SC Resolutions establishing the sanctions regimes. ${ }^{133}$ This is significant because in light of the Kadi decision, Member States of the EU might in future decide to adopt national measures individually rather than acting through the EU itself. However, as Advocate General Maduro pointed out, EU law would prevent a Member State from implementing any obligation deriving from commitments to third parties individually where the law in question overlapped with areas of EU competence. ${ }^{134}$ Considering that both EU legislation and the Orders in Council purport to implement the same SC regime, it is difficult to see how any national legislation could not fall within the jurisdiction of the CJEU for the purposes of review.

Accordingly, the CJEU, in adopting a 'parochial' approach, ensures that obligations external to the EU legal system, even if they have a higher status in the international legal order, may only penetrate the EU system under conditions determined by the CJEU itself. Such conditions include the need to comply with human rights as guaranteed by EU law. As noted above, there is still difficulty concerning access for individuals to the CJEU. Nevertheless the stance in the Kadi decision is a powerful inspiration for national courts. For as long as there is no human rights protection against the UN's own decisions through an 'international constitutional' approach, such a 'parochial' approach has its advantages.

\section{A Parochial Model in Practice}

A parochial model of human rights protection requires that each State's national courts refrain from recognizing the validity of international obligations that conflict with national human rights guarantees. Of course, this presupposes the existence of such guarantees and that they have 'primary' or constitutional status in national law. ${ }^{135}$ Examples of such an approach in practice can be found in the dialogue between the German and Italian national courts and the CJEU during the early years of European integration, where these courts reserved for themselves the ability not to recognize the supremacy of Community legislation when it conflicted with constitutional human rights

132 [2008] UKHL 26. This indeed has been the approach of AG Mengozzi (Opinion of 14 January 2010), who suggests that Regulation 881/2002, obliging Member States to freeze suspects' assets, does not permit the halting of benefits paid to the spouse of a suspect which are sufficient only to cover basic subsistence needs.

133 See explanatory notes attached to the Orders in Council cited above (n 125).

134 Above (n 122) para 30. See further Case C-260/89 ERT [1991] ECR I-2925.

135 For instance, the UK's constitutional tradition does not grant the Human Rights Act 1998 such superior status. Conflicting rules of primary legislation may receive a 'declaration of incompatibility' but cannot be invalidated (s 4). 
guarantees. ${ }^{136}$ As can be seen, it may also be possible for a 'parochial' approach to be adopted by a regional IGO relative to obligations stemming from wider IGOs or international law more generally. However, the modality of this will depend on the relationship between the legal system of that IGO, and its Member States - and at present the EU is probably a unique example, given the degree of integration between national and EU law. EU law has primacy over national law, and where the application of EU law overlaps with national law, the CJEU will prevent the EU or the Member States applying rules that conflict with the general principles of EU law. Member States may be able to avoid this supervision by legislating on these matters individually, rather than through the EU itself, though where these matters have already been legislated and struck down at the EU level, the CJEU may regard such individual measures as falling within the competence of the Union. Even so, a parochial approach could include a double layer of protection, with national courts, at the same time as the CJEU, checking on national implementation of international obligations. As discussed above, a refusal to execute these obligations may still engage international responsibility, because States may not use internal law as a justification for failure to implement their international obligations (article 27 VCLT).

\section{CONCLUDING REMARKS}

Human rights obligations developed globally and regionally since the 1950s bind all States in the world, albeit to varying degrees. In 1943, Corbett postulated that adopting a monist model of international law, where international obligations were able to take precedence over national laws, would allow for the comprehensive protection of human rights. ${ }^{137}$ However, it is argued here that this cannot hold because it is based on a false premise that the current rules on the hierarchy of norms at the international level give primacy to human rights guarantees. As can be seen, apart from the limited scope of rules of jus cogens priority between competing rules, it is based on the question of chronology, rather than substance. It also (understandably, given the time of writing) does not take into account the fact that States have gone on to create a multitude of IGOs which have not committed themselves to observing human rights standards.

136 Internationale Handelsgesellschaft $m b H v$ Einfur- und Vorrastelle fur Getreide und Futtermittel [1972] CMLR 177; Frontini v Ministero delle Finanze [1974] 2 CMLR 372.

137 PE Corbett, 'World Order-An Agenda for Lawyers' (1943) 37 AJIL 207, 212: ‘A practical consequence of monism that established the primacy of international law might be that nationassl courts, in dealing with the rights and duties of States, would act as judicial agencies to the community of States and declare any offending rule of municipal law to be ultra vires and void. This function would be analogous to that performed when they pass upon the conformity of acts of national authorities with a national constitution. How much this would simplify the enforcement of an international "bill of rights" needs no elaboration.'

\section{CAMBridge JOURNALS}


As States continue to cooperate through IGOs, it is essential to consider how to ensure that these obligations do not lose their effectiveness. The phenomenon of international integration has created the real threat that States may escape their duties to implement human rights guarantees by delegating powers to new entities without also delegating their responsibilities under human rights treaties. This article has set out how current rules relating to hierarchy in international law fail to establish sufficient safeguards for observing human rights obligations currently incumbent upon all States.

On the basis of the existing practice of different national and international courts, it has set out two possibilities that may ensure the protection of human rights. Through an 'international constitutional' approach, all IGOs could commit themselves to observing human rights guarantees, as developed through the UN, to reduce the possibility that their Member States would be obliged to prioritize their IGO obligations over their human rights obligations. Such a model could be made effective by ensuring that all proposals for action are first verified for compliance with human rights, and that judicial review would be available to challenge decisions after they were adopted. To a degree, the verification of compliance could be centralized through the creation of a single international human rights court. Alternatively, a 'parochial' model would ensure that no international obligation could penetrate a legal system (be it a national legal system or a regional legal system, such as the EU) where it conflicted with existing human rights guarantees, be they the standards accepted within that particular jurisdiction, or internationally accepted standards. As discussed above in relation to the EU's GC decision in the Kadi case, it was open to the Court to review the validity of the SC's Resolutions not merely on the basis of their incompatibility with the EU's internal rules on human rights, but also with the UN Charter's own provisions on human rights to find that the Resolutions were without force because they were adopted ultra vires. In effect, if national courts have no relevant national human rights law to apply, they could resort to reviewing the validity of the relevant international obligation with reference to international human rights law itself to establish that it is invalid, and therefore has no effect on [or in] the State in question.

The example of the ECtHR reveals potential problems with the operation of an 'international constitutional' model. Its approach highlights that for this model to protect human rights effectively, national or regional jurisdictions should only pay deference to international obligations where they emanate from an IGO that has effective human rights guarantees and mechanisms for their enforcement. At the same time one might object that a 'parochial' approach will only secure human rights protection properly where the national or regional jurisdiction in question itself contains adequate human rights guarantees. Where local human rights guarantees are inconsistent with internationally accepted standards, the adoption of a parochial model may provide cynical governments with an excuse to resist more comprehensive 
international standards and encourage the advancement of disingenuous cultural relativist arguments. Such a danger might be limited if national or regional courts were prepared to apply more comprehensive international standards in any review. Perhaps the safest approach would be to propose the two models as complementary rather than alternatives, and so ensure the maximum possibility of protection from both above and below. This would involve supervision at the level of IGOs as well as supervision at the national or regional level.

What cannot be disputed is that the gains made in human rights protection since the end of the Second World War face a real risk of erosion if efforts are not made to keep pace with developments in shifts of power and authority away from the State. Unless human rights are placed at the centre of the international system as it evolves, humankind risks forgetting one of its most significant realizations: that the advancement of human dignity should curtail and guide all exercises of authority and power.

\section{CAMBridge JOURNALS}

